\title{
Pegaharmols A-B, Axially Chiral $\beta$-Carboline-quinazoline Dimers from the Roots of Peganum harmala
}

Sheng-Ge Li, ${ }^{\dagger}$ Yue-Tong Wang, ${ }^{\dagger}$ Qin Zhang, ${ }^{\dagger}$ Kai-Bo Wang,${ }^{\S}$ Jing-Jing Xue,${ }^{\dagger}$ Da-Hong Li, ${ }^{\dagger}$ Yong-Kui Jing, ${ }^{\dagger}$ Bin Lin, ${ }^{* \bullet}$ and Hui-Ming Hua ${ }^{* \dagger}$

${ }^{\dagger}$ Key Laboratory of Structure-Based Drug Design \& Discovery, Ministry of Education, Shenyang Pharmaceutical University, Shenyang 110016, P. R. China

*Wuya College of Innovation, Shenyang Pharmaceutical University, Shenyang 110016, P. R. China ${ }^{\S}$ Department of Medicinal Chemistry and Molecular Pharmacology, College of Pharmacy, Purdue University, West Lafayette, Indiana 47907, United States

'School of Pharmaceutical Engineering, Shenyang Pharmaceutical University, Shenyang 110016, Liaoning Province, People's Republic of China

${ }^{*}$ Corresponding author

Hui-Ming Hua: huimhua@163.com

Bin Lin: randybinlin@gmail.com 


\section{CONTENTS}

1 Experimental section......................................................

1.1 General experimental procedures.........................................

1.2 Plant material.................................................................

1.3 Extraction and isolation...................................................... 1

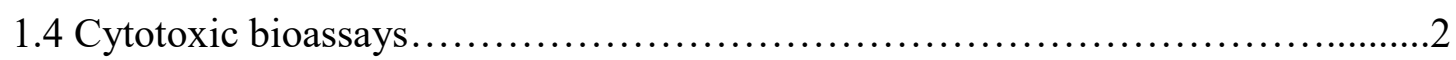

1.5 Physical and chemical data.............................................. 2

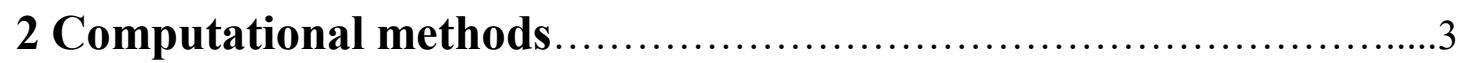

2.1 Conformation analysis grid search................................................

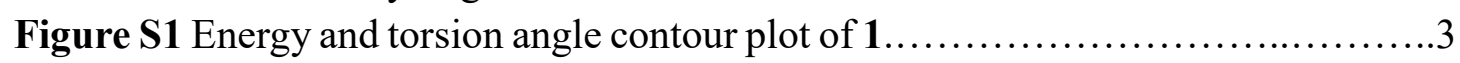

Figure S2 Structures of 1-I and 1-II.........................................

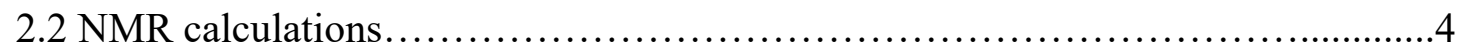

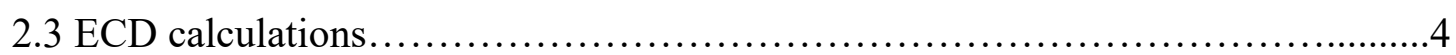

Figure S3 Linear correlations between the calculated and experimental ${ }^{13} \mathrm{C}$ NMR

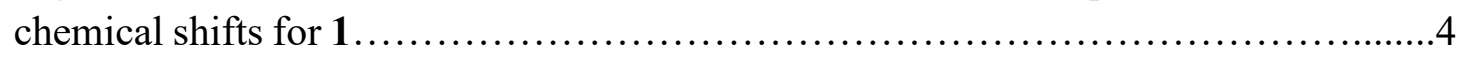

Figure S4 Experimental and calculated chemical shifts for DP4 + probability analysis for 1. (see Figure 4, Isomer 1 is conformer 1a, isomer 2 is conformer

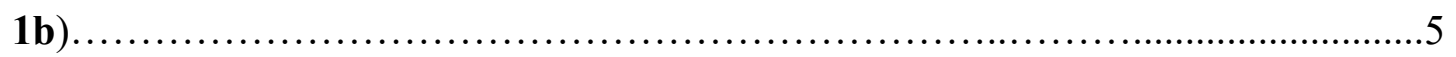

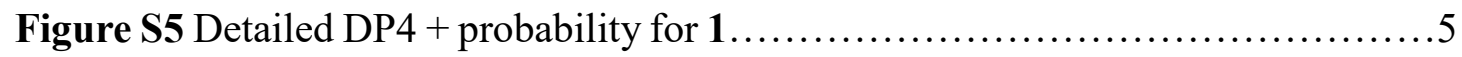

Table S1 B3LYP/6-31G(d) Optimized Lowest Energy 3D Conformers of $\mathbf{1 b}$ in ECD

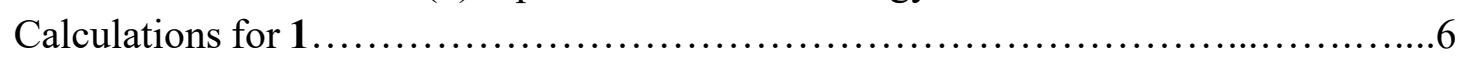

Table S2 B3LYP/6-31G(d) Optimized Lowest Energy 3D Conformers of 2a in ECD

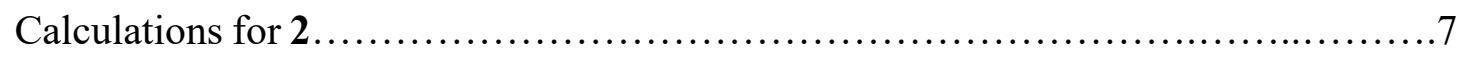

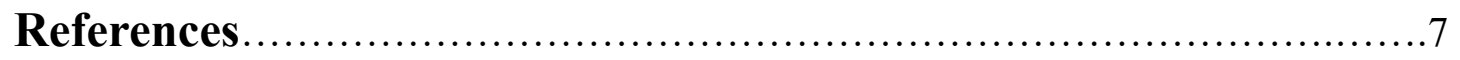

3 NMR, HR ESIMS, UV, ECD, and IR data............................... 8

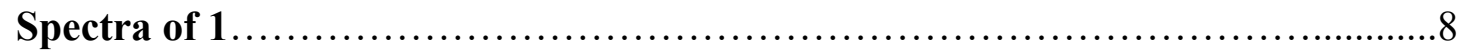

Figure S6 ${ }^{1} \mathrm{H}$ NMR spectrum $(600 \mathrm{MHz})$ of $\mathbf{1}$ in DMSO- $d_{6} \ldots \ldots \ldots \ldots \ldots \ldots \ldots \ldots \ldots . . . . \ldots$

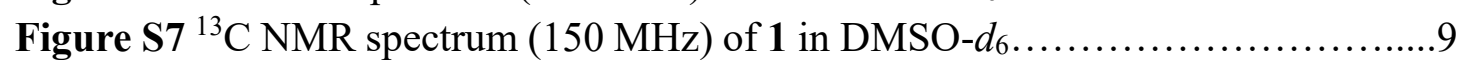

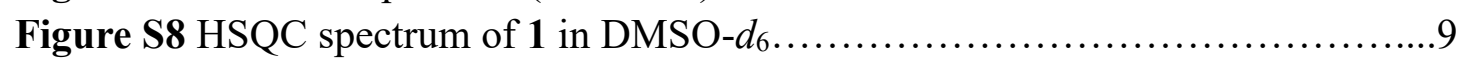

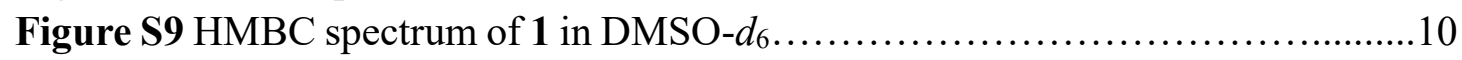

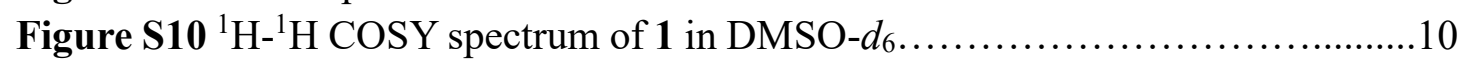

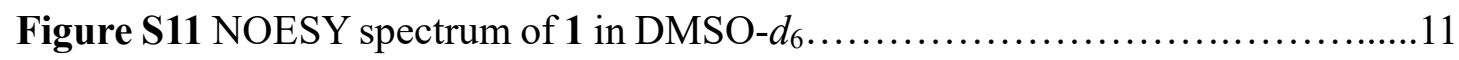

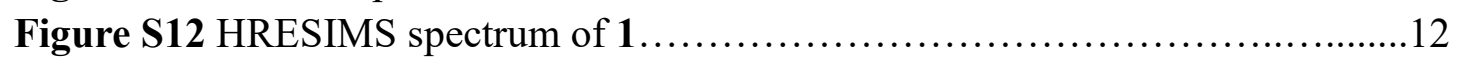

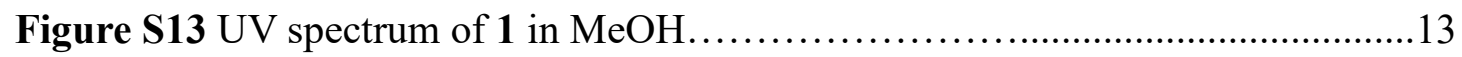

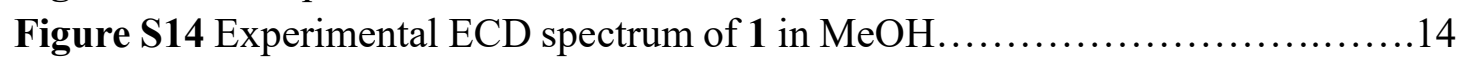

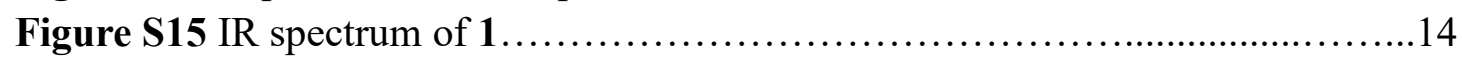

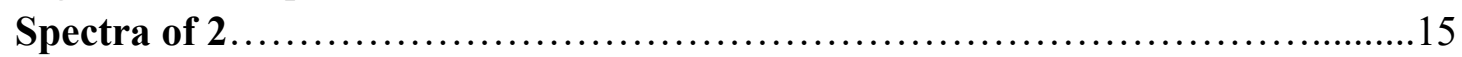


Figure S16 Key COSY, HMBC and NOESY interactions of $2 \ldots \ldots \ldots \ldots \ldots \ldots \ldots \ldots$

Figure S17 Calculated and experimental ECD spectra of 2 ........................15

Figure $\mathbf{S 1 8}{ }^{1} \mathrm{H}$ NMR spectrum $(600 \mathrm{MHz})$ of $\mathbf{2}$ in DMSO- $d_{6} \ldots \ldots \ldots \ldots \ldots \ldots \ldots \ldots$

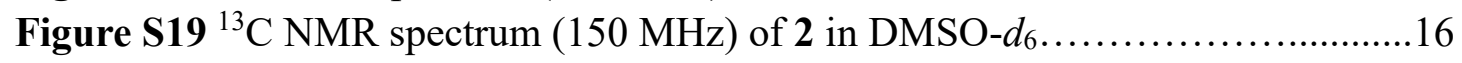

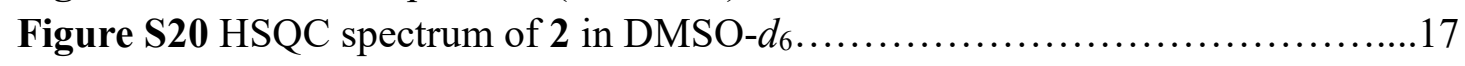

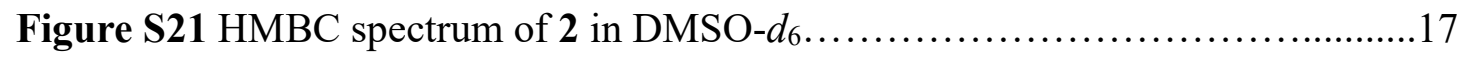

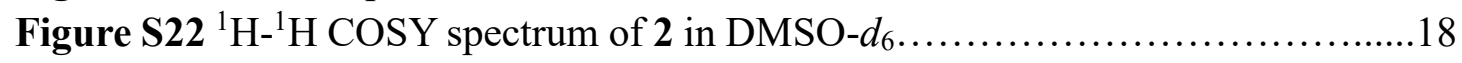

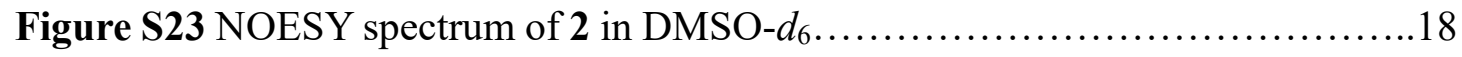

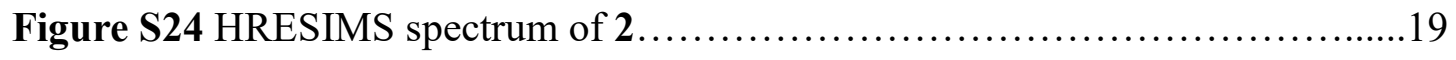

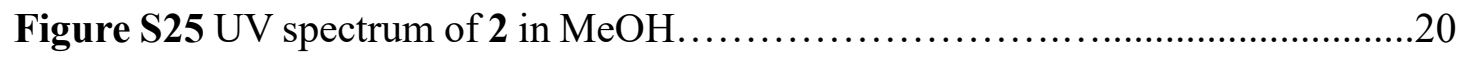

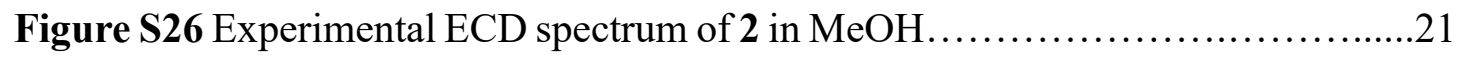

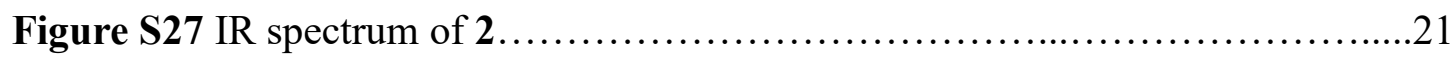




\section{Experimental section}

\subsection{General experimental procedures}

1D and 2D-NMR spectra were recorded on Bruker AV-600 NMR spectrometers using TMS as an internal standard. Mass spectra were measured on Varian QFT-ESI and Bruker micro-TOFQ-Q mass spectrometer (for HRESIMS). Optical rotations were recorded using Jasco P-2000 polarimeter. UV spectra was obtained using a Shimadzu UV-2201 spectrometer. ECD spectra were measured on Bio-logic MOS 450 spectropolarimeter. Column chromatography (CC) was performed with silica gel (Qingdao Marine Chemical Co. Ltd., Qingdao, P. R. China), ODS (50 $\mu \mathrm{m}$, YMC Co. Ltd., Kyoto, Japan), and MCI gel (120 $\mu \mathrm{m}$, CHP20/P120, Mitsubishi Chemical Co. Ltd., Japan). Preparative HPLC was conducted on a YMC-Triart C18 column $(250 \times 10 \mathrm{~mm}$ I. D., $5 \mu \mathrm{m}$ ) equipped with a LC-6AD pump and a Shimadzu SPD-20A UV-Vis detector (Shimadzu Co. Ltd., Japan).

\subsection{Plant material}

Air-dried roots of Peganum harmala were harvested from Xinjiang Uygur Autonomous region, China, in September 2015, and were confirmed by Professor Jincai $\mathrm{Lu}$ of School of Traditional Chinese Meteria Medica, Shenyang Pharmaceutical University, Shenyang, China. The voucher sample (PH201509) was deposited in the Department of Natural Products Chemistry, Shenyang Pharmaceutical University, Liaoning province, China.

\subsection{Extraction and isolation}

The roots of $P$. harmala L. $(13.0 \mathrm{~kg})$ were extracted under reflux with $95 \%$ ethanol $(3 \times 2 \mathrm{~h} \times 100 \mathrm{~L})$ via water bath on the induction cooker. The ethanol extract was concentrated in vacuo to obtain the concentrated solution (13 L) without ethanol, which was acidified to $\mathrm{pH} 2$ with $5 \% \mathrm{HCl}$ solution. The acidic mixture was partitioned with $\mathrm{CH}_{2} \mathrm{Cl}_{2}(4 \times 13 \mathrm{~L})$ to give $\mathrm{CH}_{2} \mathrm{Cl}_{2}$-soluble fraction $\mathrm{A}(200.0 \mathrm{~g})$, and the aqueous portion was then basified to $\mathrm{pH} 9$ with $3 \mathrm{~mol} / \mathrm{L} \mathrm{NaOH}$ solution, followed by thorough extraction with $\mathrm{CH}_{2} \mathrm{Cl}_{2}(4 \times 13 \mathrm{~L})$ to gain $\mathrm{CH}_{2} \mathrm{Cl}_{2}$-soluble fraction $\mathrm{B}(90.0 \mathrm{~g})$. The $\mathrm{CH}_{2} \mathrm{Cl}_{2}$-soluble fraction $\mathrm{B}$ was subjected to liquid column chromatography $(\mathrm{CC}, 5.5 \times 42 \mathrm{~cm}$, i.d $\times l$ ) over silica gel eluting with a gradient of $\mathrm{CH}_{2} \mathrm{Cl}_{2}-\mathrm{MeOH}(100: 0 \rightarrow 0: 100, \mathrm{v} / \mathrm{v})$ to yield 10 fractions (Fr. A-J). Fr. F $(26.0 \mathrm{~g})$ was separated by ODS CC $(4.0 \times 7.5 \mathrm{~cm}$, i.d $\times l)$ using $\mathrm{MeOH}-\mathrm{H}_{2} \mathrm{O}(20: 80 \rightarrow 100: 0, \mathrm{v} / \mathrm{v})$ as eluent to give six subfractions (Fr. F1-Fr. F6). Fr. F4 (10.0 g) was chromatographed over ODS CC $(4.0 \times 9.5 \mathrm{~cm}$, i.d $\times l)$ eluting with a gradient of $\mathrm{MeOH}-\mathrm{H}_{2} \mathrm{O}(20: 80 \rightarrow 100: 0, \mathrm{v} / \mathrm{v})$ to obtain six subfractions (Fr. F4.1Fr. F4.6). Fr. F4.6 (2.0 g) was isolated via MCI CC $(3.6 \times 8.5 \mathrm{~cm}$, i.d $\times l)$ with $\mathrm{MeOH}-$ $\mathrm{H}_{2} \mathrm{O}(70: 30, \mathrm{v} / \mathrm{v})$ as the mobile phase and sequently purified by semi-preparative HPLC on a YMC-Triart $\mathrm{C} 18$ column using isocratic elution of $\mathrm{MeOH}-\mathrm{H}_{2} \mathrm{O}(47: 53, \mathrm{v} / \mathrm{v})$ to afford $1\left(2.0 \mathrm{mg}, \mathrm{t}_{\mathrm{R}}=47 \mathrm{~min}\right)$ and $2\left(1.0 \mathrm{mg}, \mathrm{t}_{\mathrm{R}}=31 \mathrm{~min}\right)$. 


\subsection{Cytotoxic bioassays}

Antiproliferative activity of isolated compound 1 was tested by the trypan blue 1-2 $^{1-2}$ method using the human leukaemia cell lines (HL-60), and the MTT assay ${ }^{3}$ using the human lung cancer cell lines (A549), human breast cancer cell lines (MDA-MB-231), and human prostate cancer cell lines (DU145). The cell lines were purchased from America Type Culture Collection, ATCC (Rockville, MD, USA) and cultured in RPMI1640 medium (Gibco, New York, NY, USA) supplemented with $100 \mathrm{U} / \mathrm{mL}$ penicillin, $100 \mu \mathrm{g} / \mathrm{mL}$ streptomycin, $1 \mathrm{mM}$ glutamine and $10 \%$ heat-inactivated foetal bovine serum (Gibco).

In the trypan blue method, briefly, cells in logarithmic growth were seeded at a density of $4 \times 10^{4}$ cells $/ \mathrm{mL}$ in 24-well microplates and incubated with various concentrations of the compounds under a humidified atmosphere of $5 \% \mathrm{CO}_{2}$ and $95 \%$ air at $37^{\circ} \mathrm{C}$ for 3 days. The compound was dissolved in DMSO and then diluted to the proper concentrations. Cell viability was determined after staining the cells with trypan blue and the total cell number was determined using a hematocytometer. 5-Fluorouracil $(5-\mathrm{Fu})$ was used as a positive control.

In the MTT assay, briefly, cells suspensions, $200 \mu \mathrm{L}$, at a density of $5 \times 10^{4}$ cells $/ \mathrm{mL}$, were plated in 96-well microtiter plates and incubated for $24 \mathrm{~h}$ at $37^{\circ} \mathrm{C}$ under $5 \% \mathrm{CO}_{2}$ and $95 \%$ air. Then $2 \mu \mathrm{L}$ test compounds with different concentrations in DMSO were placed into each microtiter plates and further incubated for $72 \mathrm{~h}$. Finally, $50 \mu \mathrm{L}$ of a $0.4 \%$ MTT solution was added to each well and incubated for $4 \mathrm{~h}$. Then, the MTT was removed from the wells and the fromazan crystals were dissolved in DMSO (200 $\mu \mathrm{L})$. The plates were vibrated for $10 \mathrm{~min}$. The absorbance was then determined on a microplate reader (Bio-RAD) at the wavelength of $570 \mathrm{~nm}$. Etoposide (VP16) was used as a positive control.

\subsection{Physical and chemical data}

Pegaharmol A (1): pale-yellow solid; $[\alpha]_{\mathrm{D}}^{20}-86.8$ ( $c$ 0.18, MeOH); UV (MeOH) $\lambda \max (\log \varepsilon) 296$ (3.2), 380 (2.9) nm; for ${ }^{13} \mathrm{C}$ and ${ }^{1} \mathrm{H}$ NMR data, see Table 1; IR (KBr) $v_{\text {max }}$ : 3430, 2920, 2850, 1703, 1656, 1631, 1384; (+) HR ESIMS $m / z 464.1829$ $[\mathrm{M}+\mathrm{H}]^{+}$(calcd for $\left.\mathrm{C}_{26} \mathrm{H}_{22} \mathrm{~N}_{7} \mathrm{O}_{2}, 464.1829\right)$; $\mathrm{ECD}(\mathrm{MeOH}) \lambda \max (\Delta \varepsilon) 228(-5.2), 250$ $(+0.4), 281(-1.3), 305(+2.4) \mathrm{nm}$.

Pegaharmol B (2): pale-yellow solid; $[\alpha]_{\mathrm{D}}^{20}-37.0$ (c 0.1, $\left.\mathrm{MeOH}\right)$; UV (MeOH) $\lambda \max (\log \varepsilon) 296$ (3.1), 380 (3.0) nm; for ${ }^{13} \mathrm{C}$ and ${ }^{1} \mathrm{H}$ NMR data, see Table 1; IR (KBr) $v_{\max }$ : 3431, 2921, 2852, 2344, 1704, 1625, 1461, 1384; (+) HR ESIMS $\mathrm{m} / \mathrm{z}$ $464.1829[\mathrm{M}+\mathrm{H}]^{+}$(calcd for $\left.\mathrm{C}_{26} \mathrm{H}_{22} \mathrm{~N}_{7} \mathrm{O}_{2}, 464.1829\right)$; ECD $(\mathrm{MeOH}) \lambda \max (\Delta \varepsilon) 228(+$ $10.3), 254(+1.0), 282(+6.1), 309(-7.5) \mathrm{nm}$. 


\section{Computational methods}

\subsection{Conformation analysis grid search}

The calculation was executed in Gaussian 09 software using a grid search. The torsion angle on $\mathrm{C}_{7}-\mathrm{C}_{8}-\mathrm{C}_{9^{\prime \prime}}-\mathrm{N}_{10}$ was altered from $-105^{\circ}$ to $255^{\circ}$ in $10^{\circ}$ increments in 1, covering the complete conformers about this torsion bond (Figure S1).

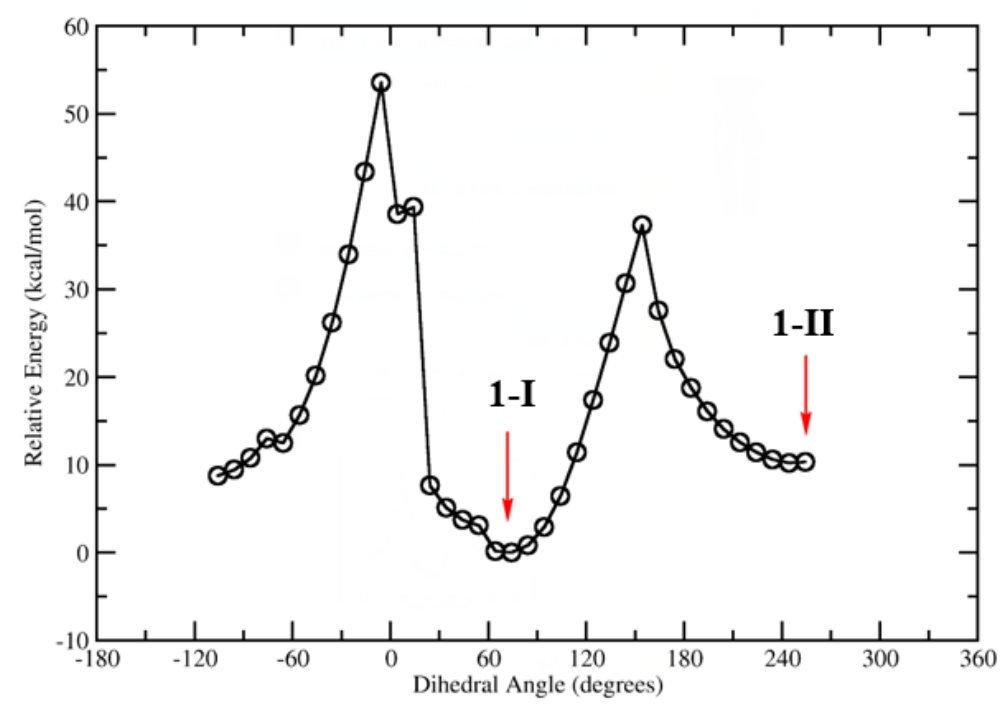

Figure S1 Energy and torsion angle contour plot of 1

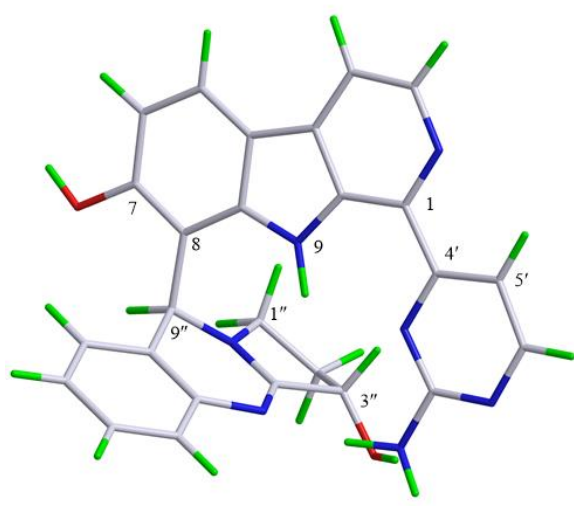

$1-\mathrm{I}(0.17 \mathrm{kcal} / \mathrm{mol})$

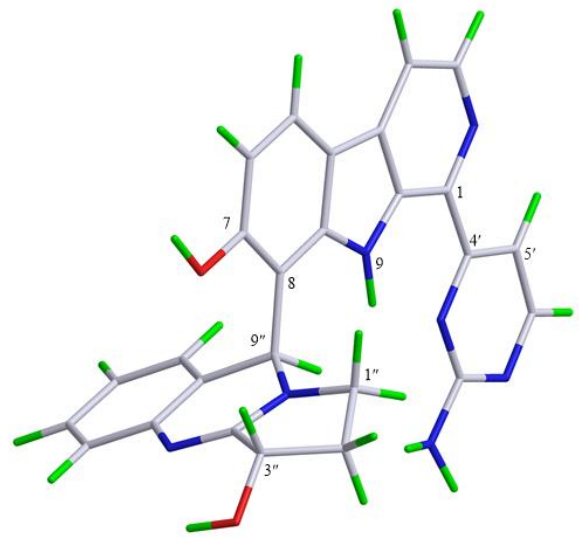

1-II $(10.21 \mathrm{kcal} / \mathrm{mol})$

Figure S2 Structures of 1-I and 1-II 


\subsection{NMR calculations}

Conformational searches for compounds 1a and $\mathbf{1 b}$ (Figure 4) were conducted by CONFLEX software with MMFF94s force field. All the conformers whose Boltzmann distribution is more than $1 \%$ were optimized at the B3LYP/6-31G(d) level in DMSO using the polarizable continuum model (PCM) solvent model with the Gaussian 09 program package. ${ }^{4}$ The gauge independent atomic orbital (GIAO) shielding constants of these conformers were calculated at the mPW1PW91/6-311+G(d,p) level after geometry optimization. Boltzmann-weighted averages of the chemical shifts were calculated to scale them against the experimental values. The experimental and calculated data were analyzed by the linear correlation coefficients $R^{2}$ (Figure S3) and the modified probability DP4 + method (Figures S4 and S5) for stereoisomers. ${ }^{5}$

\subsection{ECD calculations}

Those conformers of compound $\mathbf{1 b}$ used for ECD calculations were consistent with the ones selected for NMR calculation. Conformational search for compound 2a was conducted by CONFLEX software with MMFF94s force field. All the conformers whose Boltzmann distribution is more than $1 \%$ were optimized at the B3LYP/6-31G(d) level in $\mathrm{MeOH}$ using PCM solvent model with the Gaussian 09 program package. ${ }^{4} \mathrm{ECD}$ calculations of all the conformers of $\mathbf{1 b}$ and $\mathbf{2 a}$ were run by the time-dependent density functional theory (TDDFT) method at B3LYP/6-311G++(2d,p) level in $\mathrm{MeOH}$ with the PCM solvent model The overall calculated ECD spectra were generated by Boltzmann weighting using SpecDis $1.51 .^{6}$
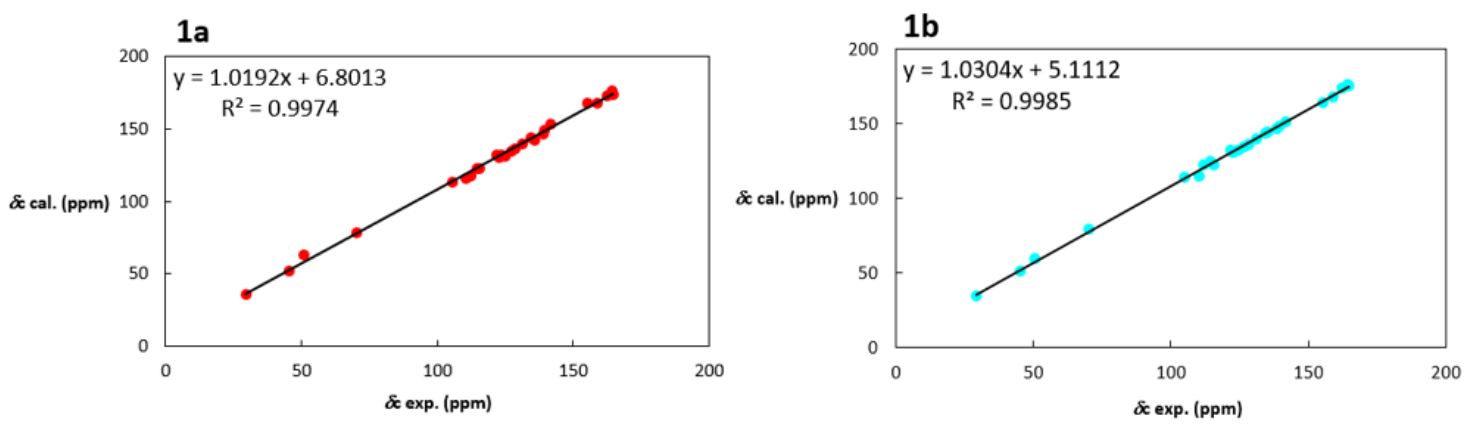

Figure S3 Linear correlations between the calculated and experimental ${ }^{13} \mathrm{C}$ NMR chemical shifts for 1 


\begin{tabular}{|c|c|c|c|c|c|c|c|}
\hline \multicolumn{2}{|c|}{$\begin{array}{l}\text { Functional } \\
\text { mPW1P[T } 91\end{array}$} & \multicolumn{2}{|c|}{$\begin{array}{l}\text { Solvent? } \\
\text { PCy }\end{array}$} & \multicolumn{2}{|c|}{$\begin{array}{l}\text { Basis Set } \\
6-311+G(\text { d. p) }\end{array}$} & \multicolumn{2}{|c|}{$\begin{array}{l}\text { Type of Data } \\
\text { Unscaled Shifts }\end{array}$} \\
\hline & & DP4+ & $0.00 \%$ & $100.00 \%$ & - & - & - \\
\hline Nuclei & $5 p 2 ?$ & sperimenta & Isomer 1 & Isomer 2 & Isomer 3 & Isomer 4 & Isomer 5 \\
\hline $\mathrm{C}$ & $x$ & 135.4 & 142.86466 & 144. 53134 & & & \\
\hline c & $\mathrm{x}$ & 138.6 & 147. 27971 & 146. 84023 & & & \\
\hline c & $x$ & 115.4 & 123. 30943 & 122. 46409 & & & \\
\hline c & $x$ & 131.0 & 139. 88629 & 140.05761 & & & \\
\hline c & $x$ & 114.2 & 122. 73756 & 124. 79794 & & & \\
\hline c & $x$ & 122.4 & 130.99121 & 130.42326 & & & \\
\hline c & $x$ & 110.1 & 116. 49716 & 115.09064 & & & \\
\hline c & $x$ & 155.1 & 167. 88131 & 163. 84939 & & & \\
\hline c & $x$ & 112. 1 & 117. 59241 & 122. 53311 & & & \\
\hline c & $x$ & 139.4 & 149. 062 & 148. 39079 & & & \\
\hline c & $x$ & 134.3 & 144. 60895 & 143. 88832 & & & \\
\hline c & $x$ & 164. 1 & 176. 8008 & 175.93858 & & & \\
\hline c & $x$ & 164.6 & 173. 99649 & 175.70438 & & & \\
\hline c & $x$ & 158.8 & 168. 30059 & 168. 17626 & & & \\
\hline c & $x$ & 105.1 & 113. 7401 & 114. 11231 & & & \\
\hline c & & 50.5 & 63.58306 & 59. 21836 & & & \\
\hline c & & 45.1 & 52. 17634 & 50. 94984 & & & \\
\hline c & & 29.2 & 36.04434 & 34. 34389 & & & \\
\hline c & & 70.2 & 78.6447 & 78. 99661 & & & \\
\hline c & $x$ & 162. 4 & 173. 27205 & 174.24565 & & & \\
\hline c & $x$ & 141. 6 & 153. 81238 & 151. 24525 & & & \\
\hline c & $x$ & 123. 2 & 132. 30849 & 131. 7838 & & & \\
\hline c & $x$ & 128.4 & 136. 3631 & 135.85851 & & & \\
\hline c & $x$ & 124.6 & 131. 99166 & 131. 89859 & & & \\
\hline c & $x$ & 126.8 & 135.1837 & 134. 74607 & & & \\
\hline c & $x$ & 121.6 & 132. 05994 & 131.89438 & & & \\
\hline H & & 6. 84 & 7.01853 & 7. 32208 & & & \\
\hline H & & 4. 64 & 5. 02491 & 5. 47367 & & & \\
\hline $\mathrm{H}$ & $x$ & 6.9 & 7. 45141 & 7. 54724 & & & \\
\hline $\mathrm{H}$ & $x$ & 6.9 & 7. 3811 & 7. 38713 & & & \\
\hline H & $x$ & 7. 12 & 7. 68782 & 7. 62072 & & & \\
\hline $\mathrm{H}$ & $x$ & 7. 12 & 7. 542 & 7. 62338 & & & \\
\hline $\mathrm{H}$ & & 3.28 & 3. 49583 & 3. 53706 & & & \\
\hline $\mathrm{H}$ & & 2. 76 & 3. 3473 & 3. 25831 & & & \\
\hline $\mathrm{H}$ & & 1. 77 & 2. 09654 & 2. 11242 & & & \\
\hline H & & 2. 1 & 2. 54082 & 2. 39828 & & & \\
\hline $\mathrm{H}$ & $x$ & 8.09 & 8. 46292 & 8. 35348 & & & \\
\hline $\mathrm{H}$ & $x$ & 8.4 & 9. 01116 & 8. 90004 & & & \\
\hline $\mathrm{H}$ & $x$ & 7.64 & 8. 54836 & 8. 53824 & & & \\
\hline H & $x$ & 8. 37 & 8. 9056 & 8. 87961 & & & \\
\hline $\mathrm{H}$ & $x$ & 8.06 & 8. 52346 & 8. 4742 & & & \\
\hline $\mathrm{H}$ & $x$ & 7 & 7. 14021 & 7. 25266 & & & \\
\hline
\end{tabular}

Figure S4 Experimental and calculated chemical shifts for DP4 + probability analysis for $\mathbf{1}$ (see Figure 4, Isomer 1 is conformer $\mathbf{1 a}$, isomer 2 is conformer $\mathbf{1 b}$ )

\begin{tabular}{|c|c|c|c|c|c|c|}
\hline $\begin{array}{l}\text { Functional } \\
\text { लPण1Pम91 }\end{array}$ & \multicolumn{2}{|c|}{$\begin{array}{l}\text { Solvent? } \\
\text { PCI }\end{array}$} & \multicolumn{2}{|c|}{$\begin{array}{c}\text { Basis Set } \\
6-311+G(d, p)\end{array}$} & \multicolumn{2}{|c|}{$\begin{array}{l}\text { Type of Data } \\
\text { Unscaled Shifts }\end{array}$} \\
\hline & Isoner 1 & Isoner 2 & Isoner 3 & Isoner 4 & Isoner 5 & Isoner 6 \\
\hline sDP4+ (H data) & $30.97 \%$ & $469.03 x$ & - & - & - & - \\
\hline sDP4+ (C data) & $0.83 \%$ & $499.17 \%$ & - & - & - & - \\
\hline sDP4+ (all data) & $0.37 s$ & 199.635 & - & - & - & - \\
\hline uDP4+ (H data) & $609.48 \%$ & $30.52 \%$ & - & - & - & - \\
\hline uDP4+ (C data) & $0.06 \%$ & 499.945 & - & - & - & - \\
\hline uDP4+ (all data) & $0.13 \mathrm{~s}$ & 99.875 & - & - & - & - \\
\hline DP4+ (H data) & $450.53 \%$ & 49. 47s & - & - & - & - \\
\hline DP4+ (C data) & $0.00 \mathrm{~s}$ & $100.00 \mathrm{~s}$ & - & - & - & - \\
\hline DP4+ (all data) & $0.00 \mathrm{~s}$ & $100.00 \mathrm{~s}$ & - & - & - & - \\
\hline
\end{tabular}

Figure S5 Detailed DP4 + probability for 1 
Table S1 B3LYP/6-31G(d) Optimized Lowest Energy 3D Conformers of 1b in ECD Calculations for 1

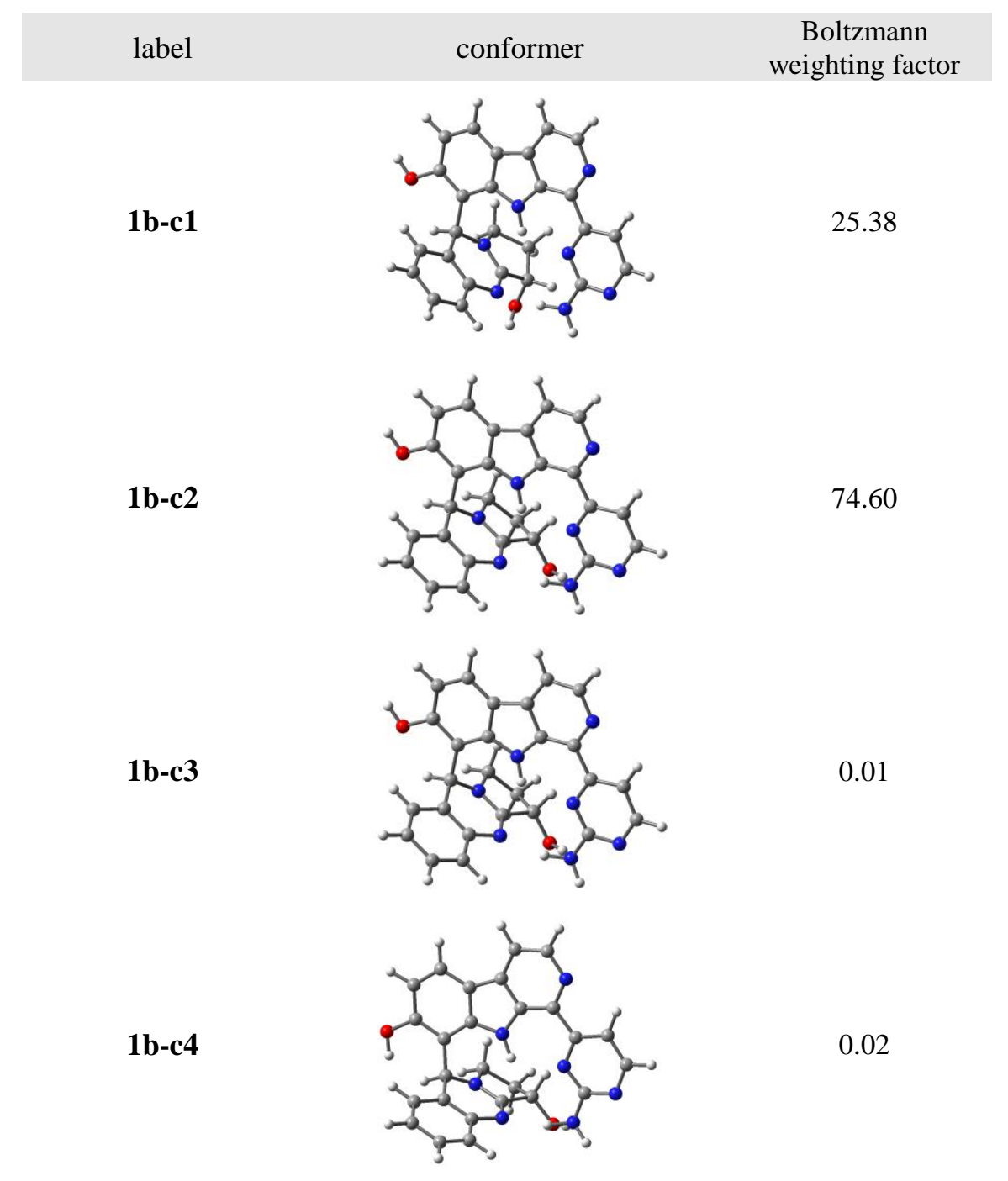


Table S2 B3LYP/6-31G(d) Optimized Lowest Energy 3D Conformers of 2a in ECD Calculations for 2

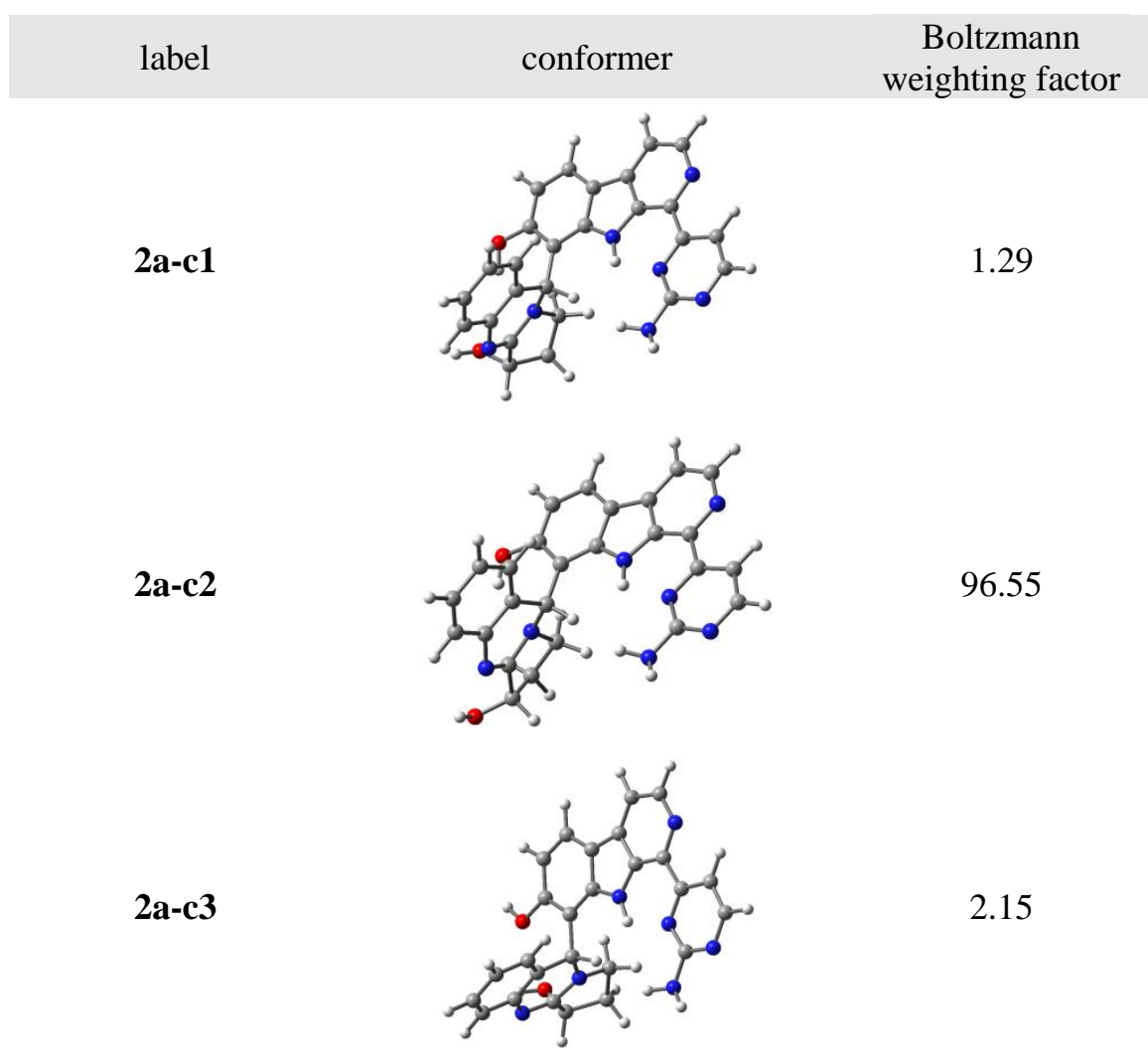

\section{References:}

(1) Wang, K. B.; Li, D. H.; Hu, P.; Wang, W. J.; Lin, C.; Wang, J.; Lin, B.; Bai, J.; Pei, Y. H.; Jing, Y. K.; Li, Z. L.; Yang, D. Z.; Hua, H. M. Org. Lett. 2016, 16, 3398-3401.

(2) Wang, F.; Hua, H. M.; Pei, Y. H.; Chen, D.; Jing, Y. K. J. Nat. Prod. 2006, 69, 807-810.

(3) Mosmann, T. J. J. Immunol. Methods 1983, 65, 55-63.

(4) Frisch, M. J.; Trucks, G. W.; Schlegel, H. B.; Scuseria, G. E.; Robb, M. A.; Cheeseman, J. R.; Scalmani, G.; Barone, V.; Mennucci, B.; Petersson, G. A.; Nakatsuji, H.; Caricato, M.; Li, X.; Hratchian, H. P.; Izmaylov, A. F.; Bloino, J.; Zheng, G.; Sonnenberg, J. L.; Hada, M.; Ehara, M.; Toyota, K.; Fukuda, R.; Hasegawa, J.; Ishida, M.; Nakajima, T.; Honda, Y.; Kitao, O.; Nakai, H.; Vreven, T.; Montgomery, J. A.; Jr; Peralta, J. E.; Ogliaro, F.; Bearpark, M.; Heyd, J. J.; Brothers, E.; Kudin, K. N.; Staroverov, V. N.; Kobayashi, R.; Normand, J.; Raghavachari, K.; Rendell, A.; Burant, J. C.; Iyengar, S. S.; Tomasi, J.; Cossi, M.; Rega, N.; Millam, J. M.; Klene, M.; Knox, J. E.; Cross, J. B.; Bakken, V.; Adamo, C.; Jaramillo, J.; Gomperts, R.; Stratmann, R. E.; Yazyev, 
O.; Austin, A. J.; Cammi, R.; Pomelli, C.; Ochterski, J. W.; Martin, R. L.; Morokuma, K.; Zakrzewski, V. G.; Voth, G. A.; Salvador, P.; Dannenberg, J. J.; Dapprich, S.; Daniels, A. D.; Farkas, O.; Foresman, J. B.; Ortiz, J. V.; Cioslowski, J.; Fox, D. J. Gaussian 09, Wallingford, CT, 2010 .

(5) (a) Grimblat, N.; Zanardi, M. M.; Sarotti, A. M. J. Org. Chem. 2015, 80, 12526-12534. (b) Wang, J.; Ren, Q.; Zhang, Y.; Guo, R.; Lin, B.; Huang, X.; Song, S. Fitoterapia 2019, 138, 104352

(6) Bruhn, T.; Hemberger, Y.; Schaumlöffel, A.; Bringmann, G. Spec Dis, version 1.51; Germany, 2010.

\section{NMR, HR ESIMS, UV, ECD, and IR data}

\section{Spectra of 1}

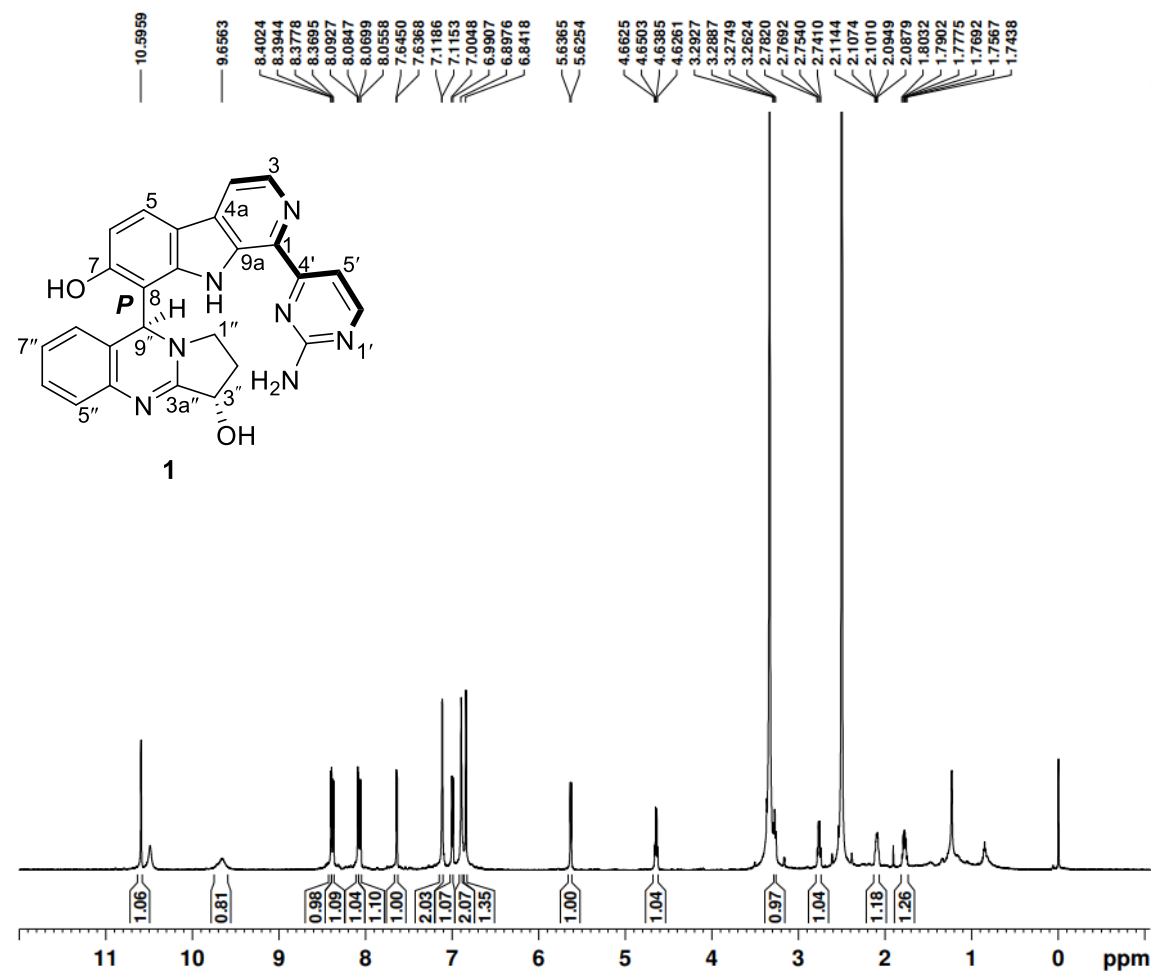

Figure S6 ${ }^{1} \mathrm{H}$ NMR spectrum $(600 \mathrm{MHz})$ of 1 in DMSO-d 


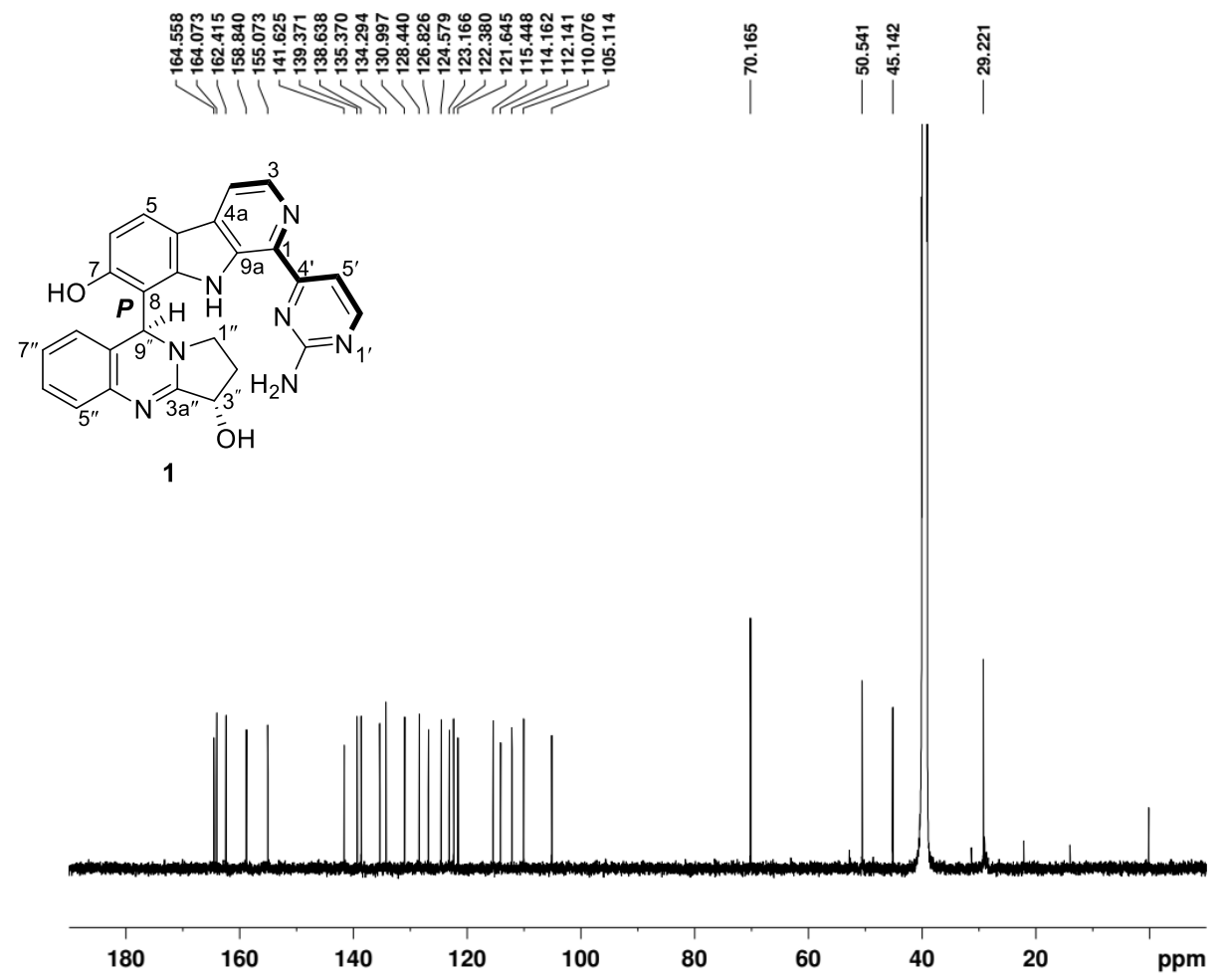

Figure $\mathbf{S} 7{ }^{13} \mathrm{C}$ NMR $(150 \mathrm{MHz})$ spectrum of $\mathbf{1}$ in DMSO- $d_{6}$

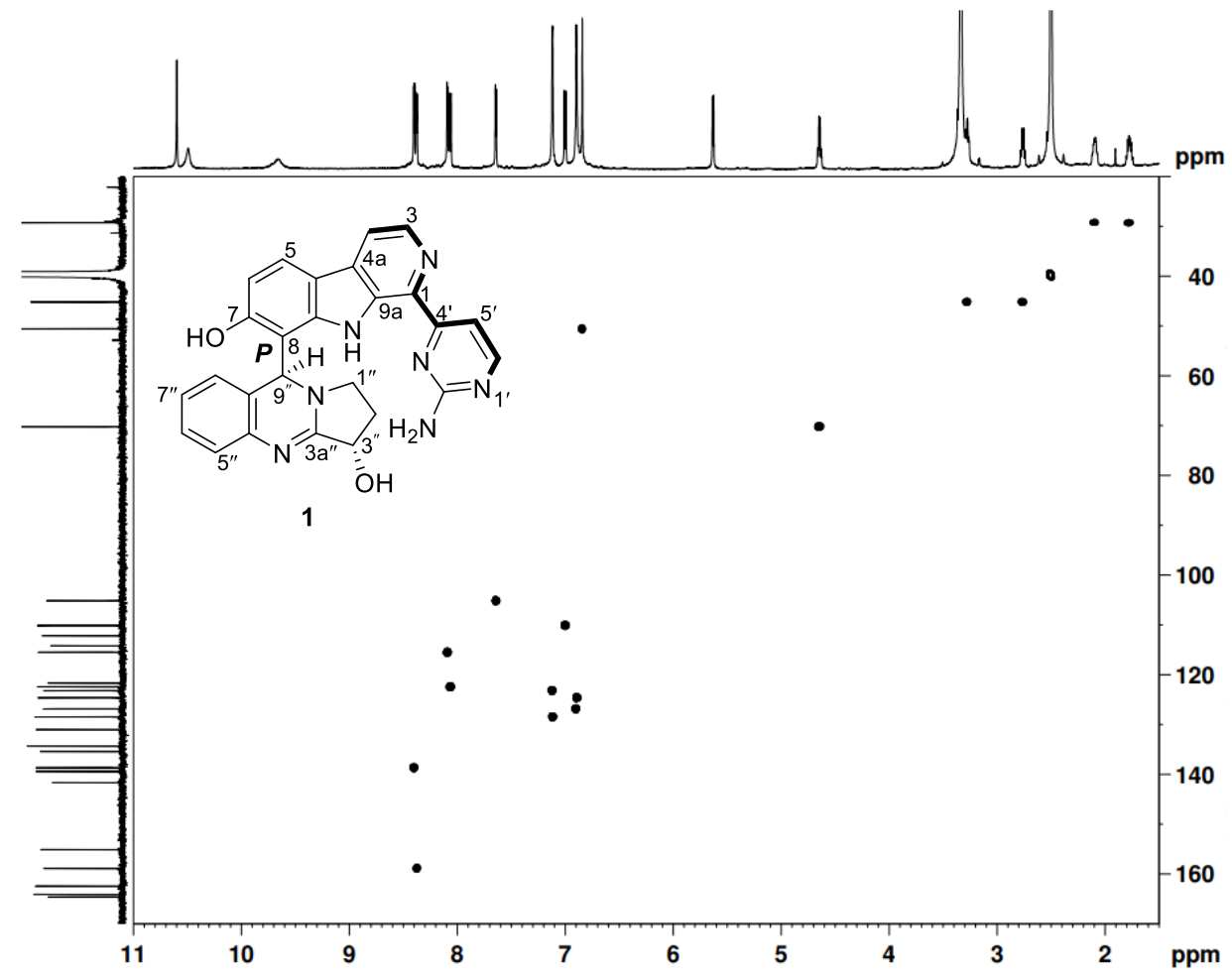

Figure S8 HSQC spectrum of 1 in DMSO- $d_{6}$ 


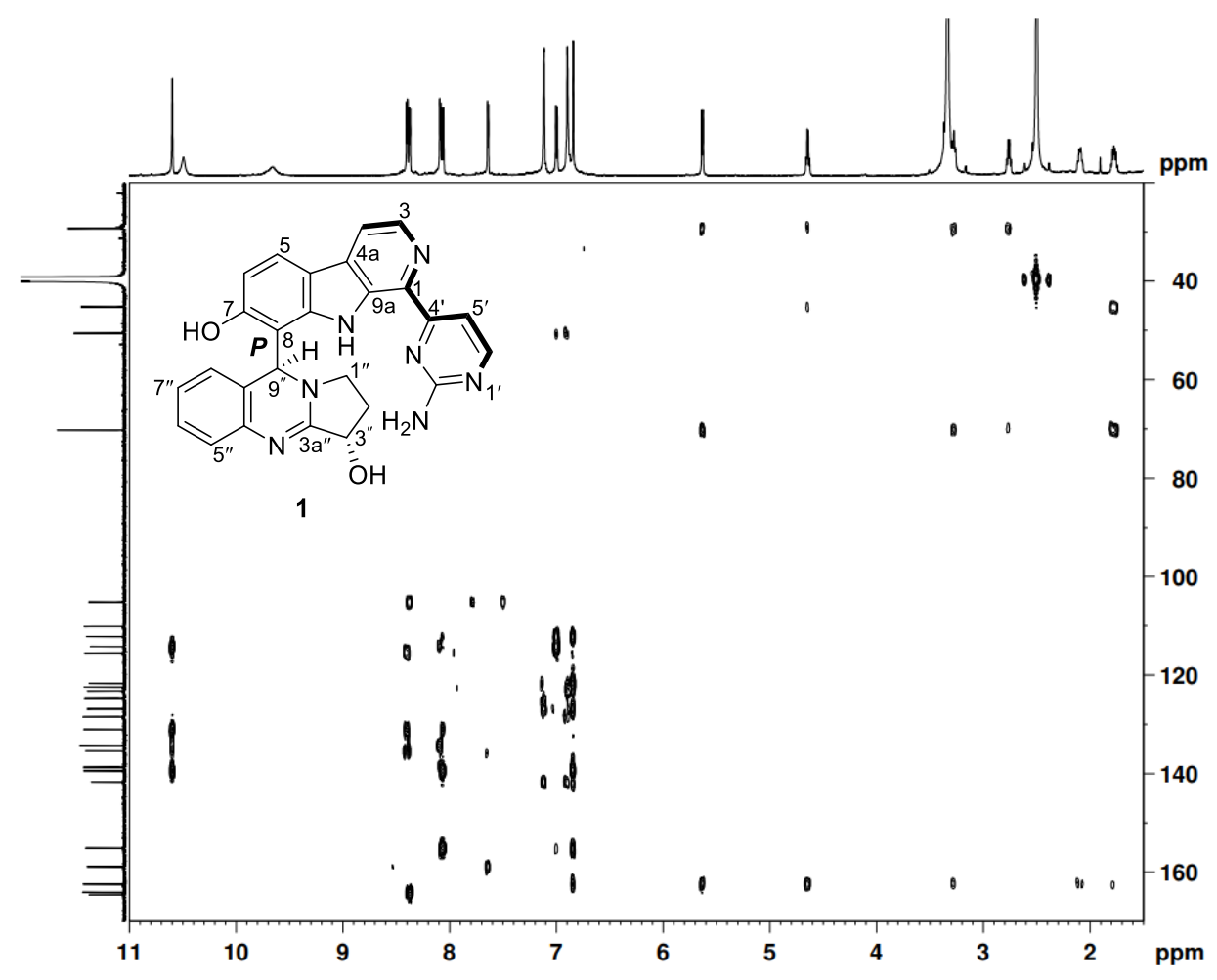

Figure S9 HMBC spectrum of 1 in DMSO- $d_{6}$

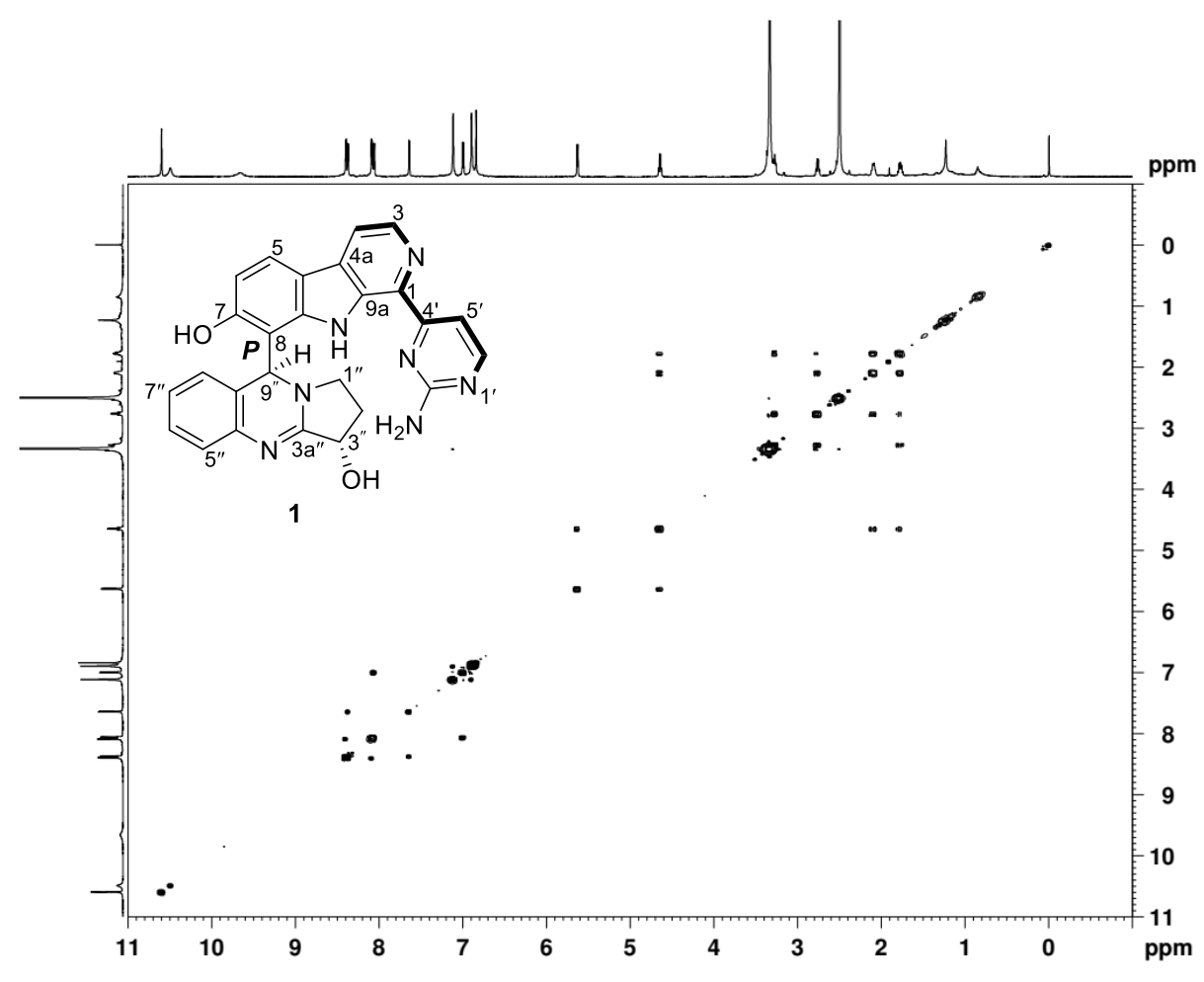

Figure $\mathbf{S 1 0}{ }^{1} \mathrm{H}-{ }^{1} \mathrm{H}$ COSY spectrum of 1 in DMSO- $d_{6}$ 


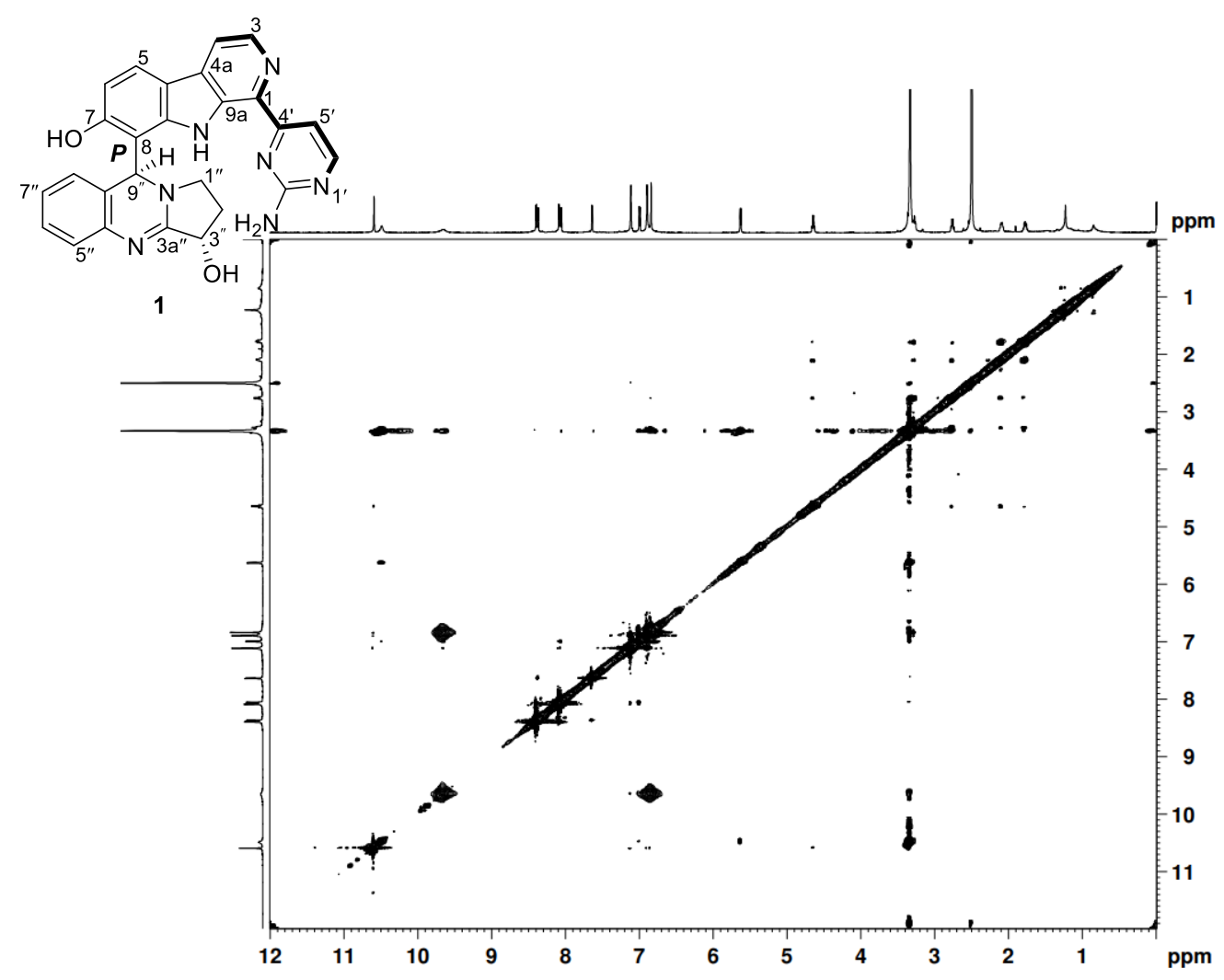

Figure S11 NOESY spectrum of 1 in DMSO- $d_{6}$ 


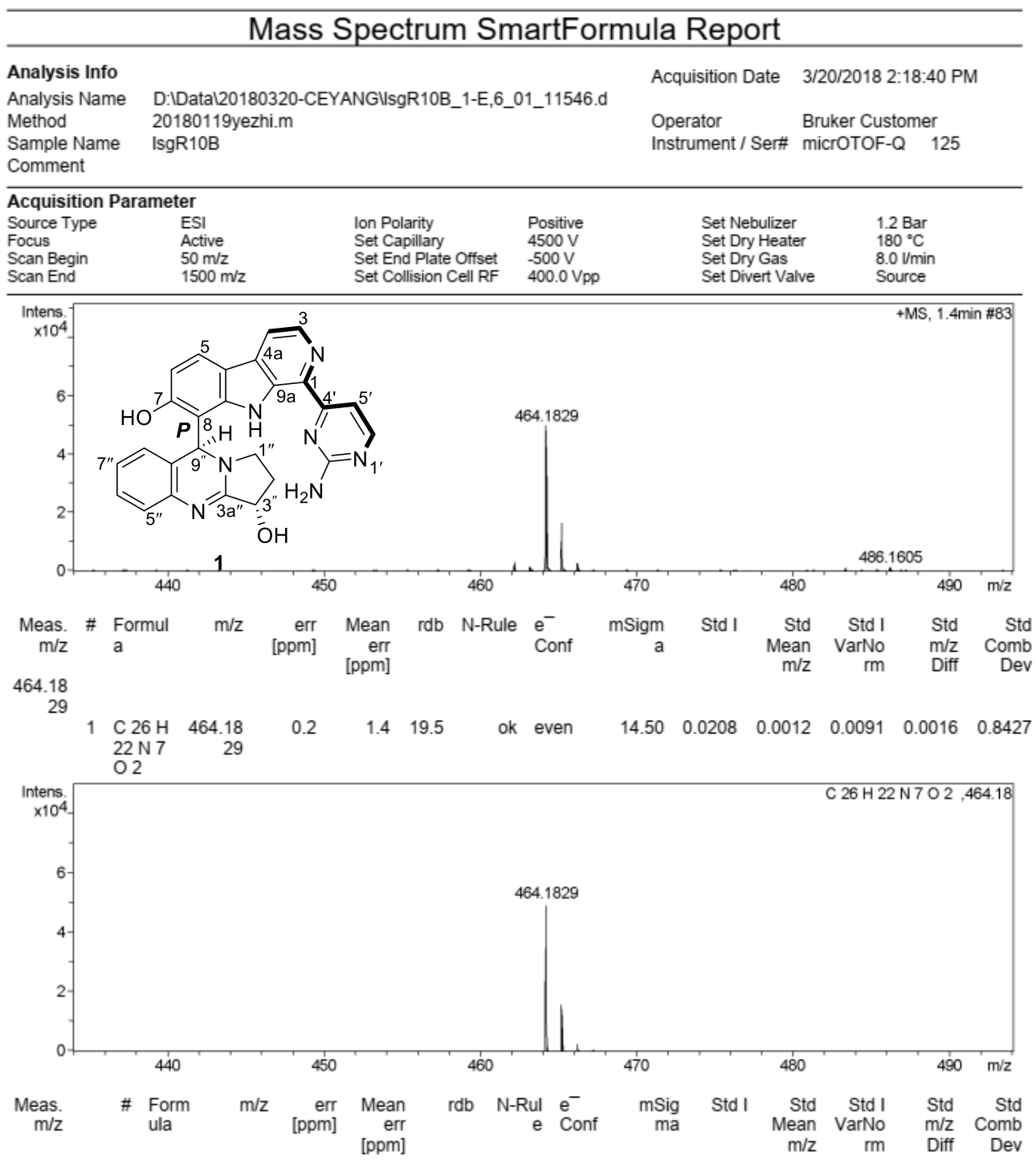

Figure S12 HRESIMS spectrum of 1 
Data Set: 没有

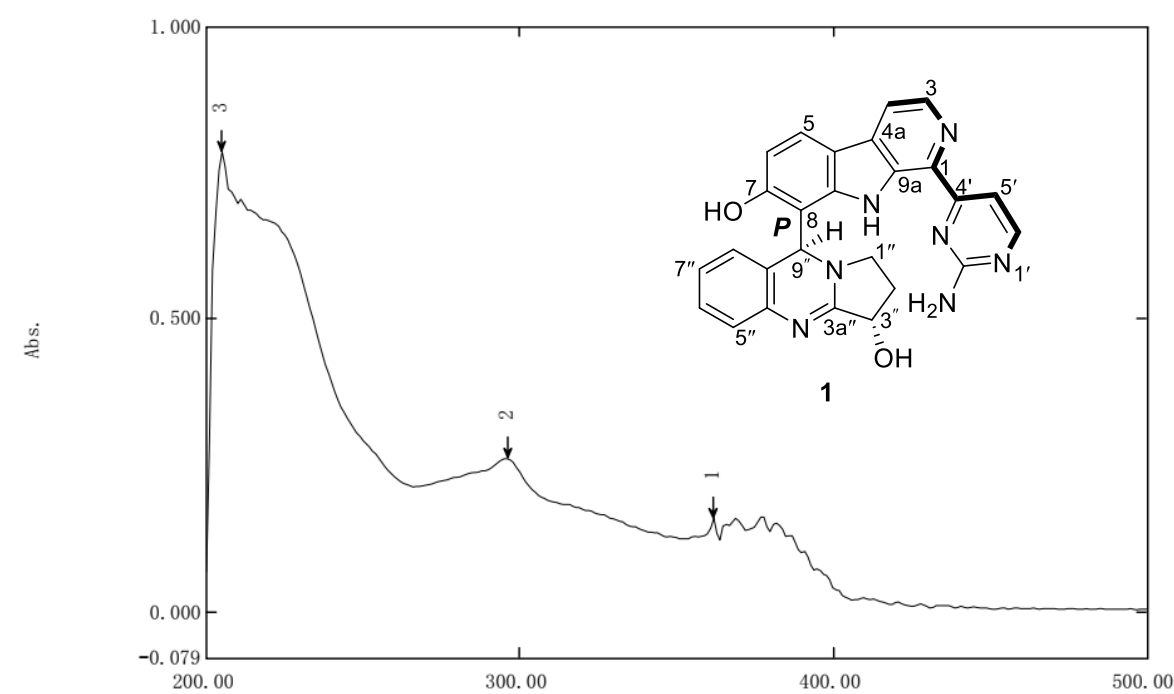

\section{测定属性}

波长范围 $(\mathrm{nm}$.$) ）２00.00到800.00$

扫描速度：中速

采样间隔: 1.0

自动采样间隔: 停用

扫描模式: 单一的

试样准备属性

重量:

体积:

希释:

光程长:
附加信息:

仪器属性

仪器类型： UV-1700

测定方式: 吸收值

狭涟宽: $1.0 \mathrm{~nm}$

光源改变波长: $360.0 \mathrm{~nm}$

$\mathrm{S} / \mathrm{R}$ 转换: 标准

附件属性

附件:

nm.
\begin{tabular}{|r|c|r|r|l|}
\hline No. & P/V & Wavelength & Abs. & 描述 \\
\hline 1 & ( & 362.00 & .159 & \\
\hline 2 & $\oplus$ & 296.00 & .261 & \\
\hline 3 & $\Phi$ & 205.00 & .786 & \\
\hline 4 & $\mathbf{\Phi}$ & 364.00 & .123 & \\
\hline 5 & $\mathbf{\Phi}$ & 266.00 & .213 & \\
\hline
\end{tabular}

FIELD TEXT

Figure S13 UV spectrum of $\mathbf{1}$ in $\mathrm{MeOH}$ 


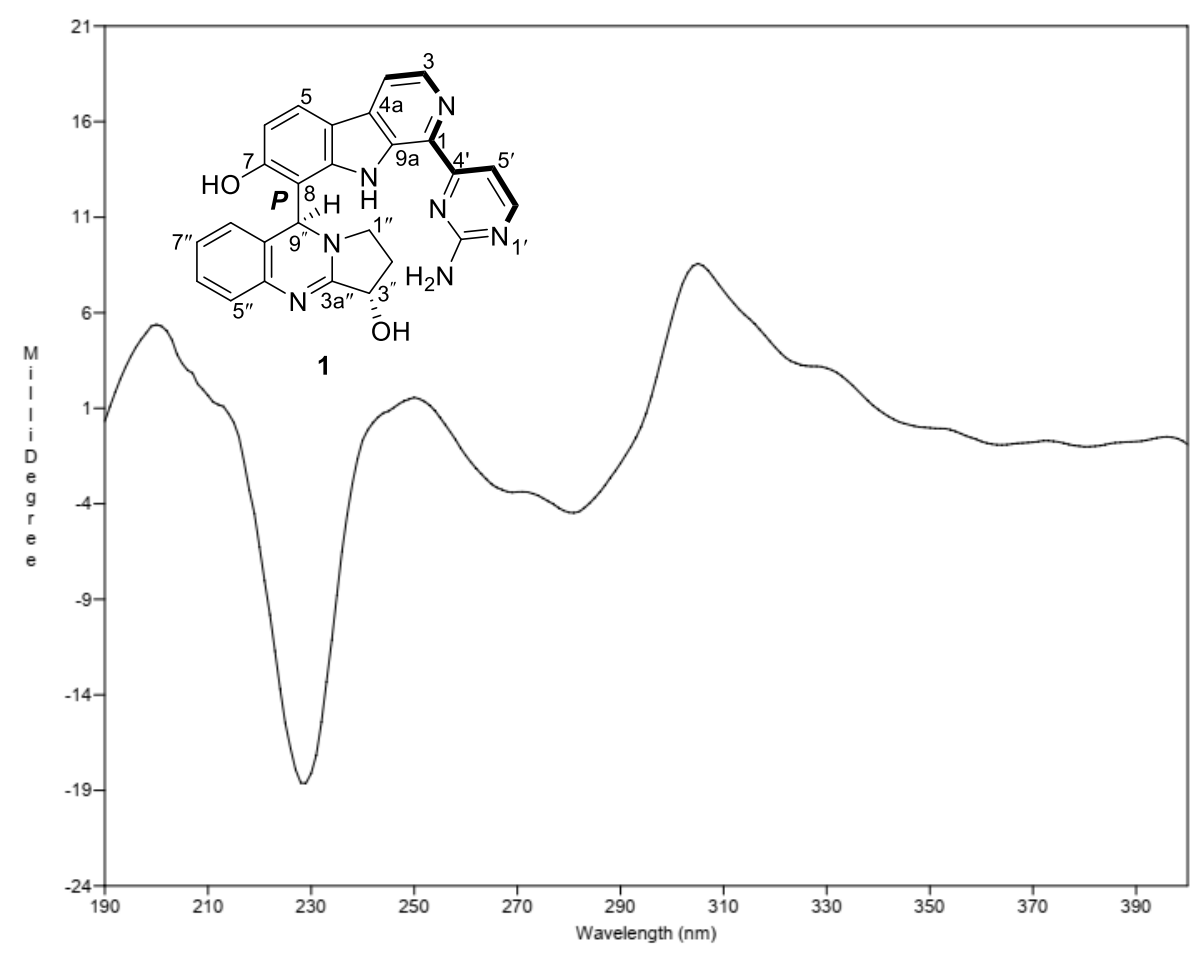

Bio-Kine Software V4.74 Date : 2019-9-26 Time : 14:43:58

COMMENTS :

File name : sav-golay

Savitzky-Golay Smooth of sav-golay

Window Points $=15$

Polynomial Order $=3$
Derivative $=0$

Figure S14 Experimental ECD spectrum of 1 in $\mathrm{MeOH}$

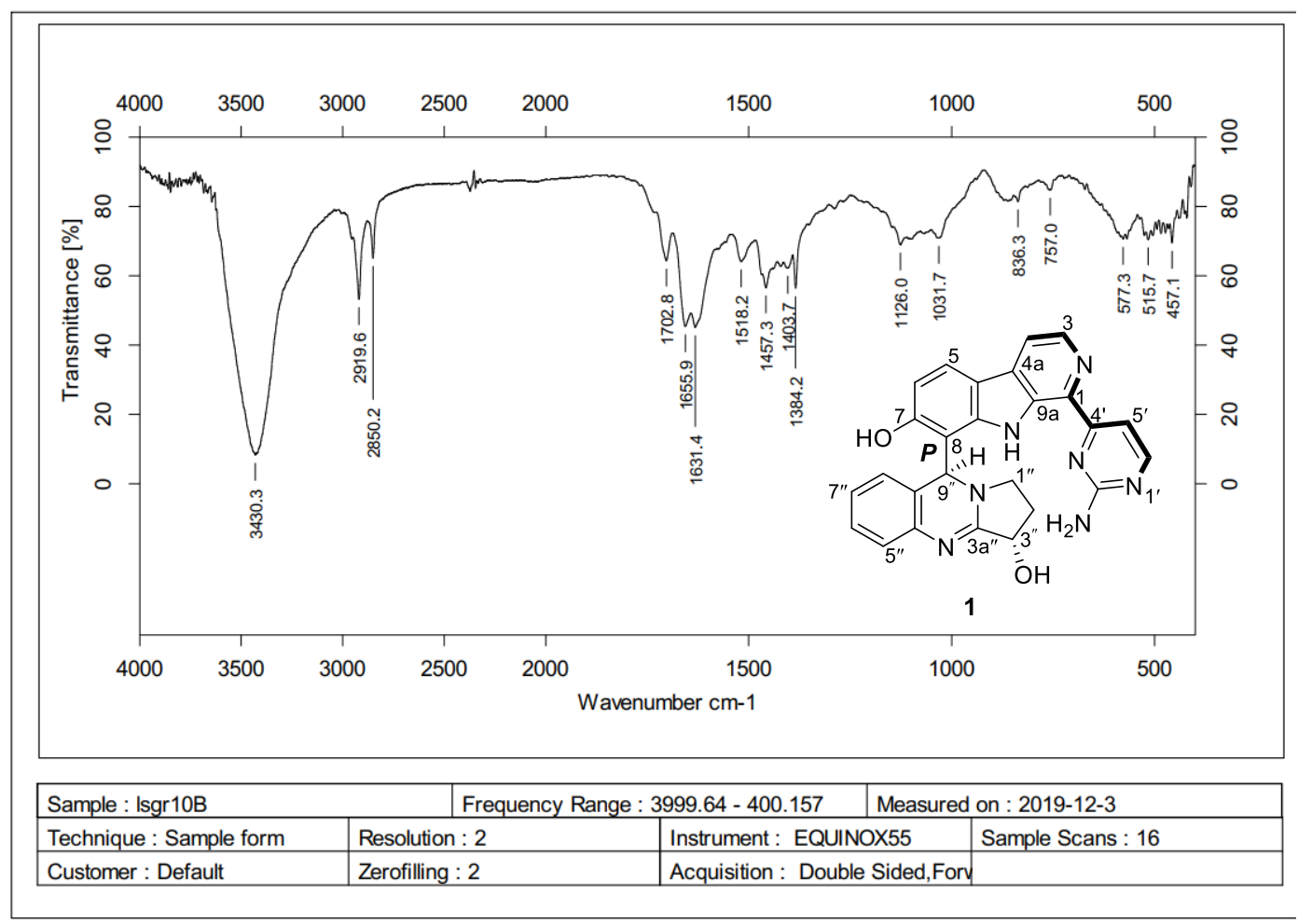

Figure S15 IR spectrum of 1 


\section{Spectra of 2}
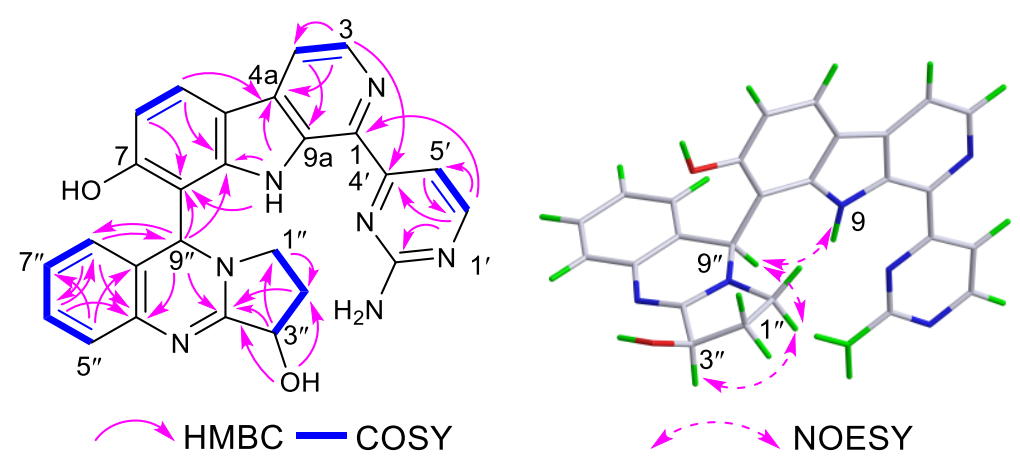

Figure S16 Key COSY, HMBC and NOESY interactions of 2

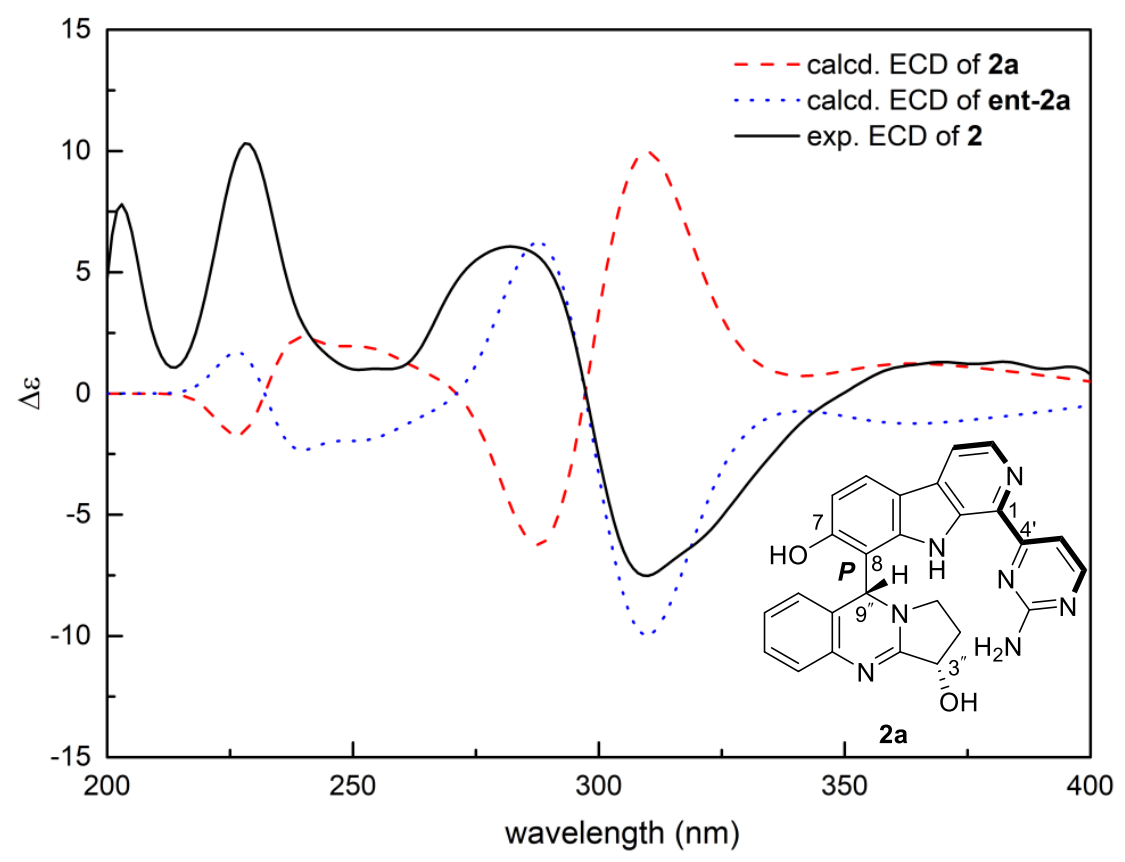

Figure S17 Calculated and experimental ECD spectra of 2 

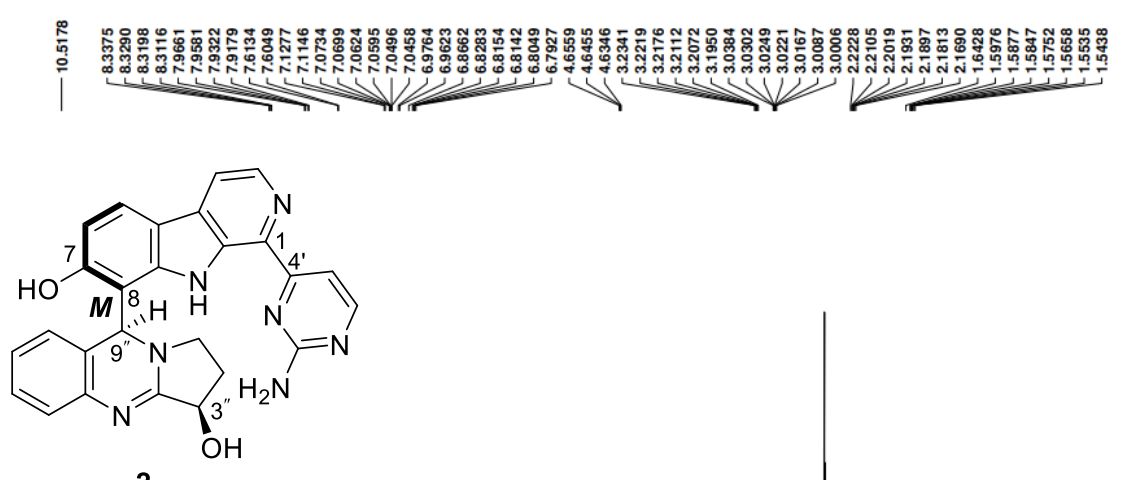

2

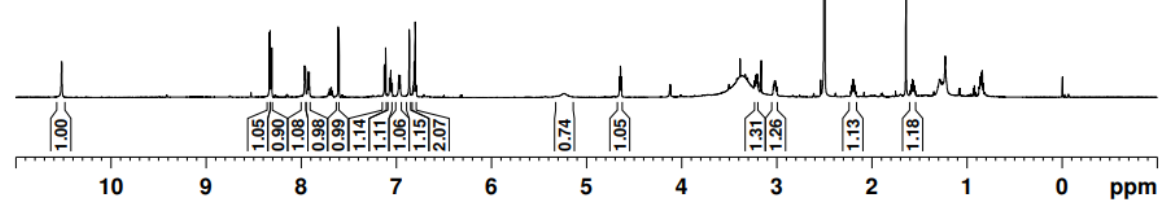

Figure S18 ${ }^{1} \mathrm{H}$ NMR spectrum $(600 \mathrm{MHz})$ of 2 in DMSO- $d_{6}$
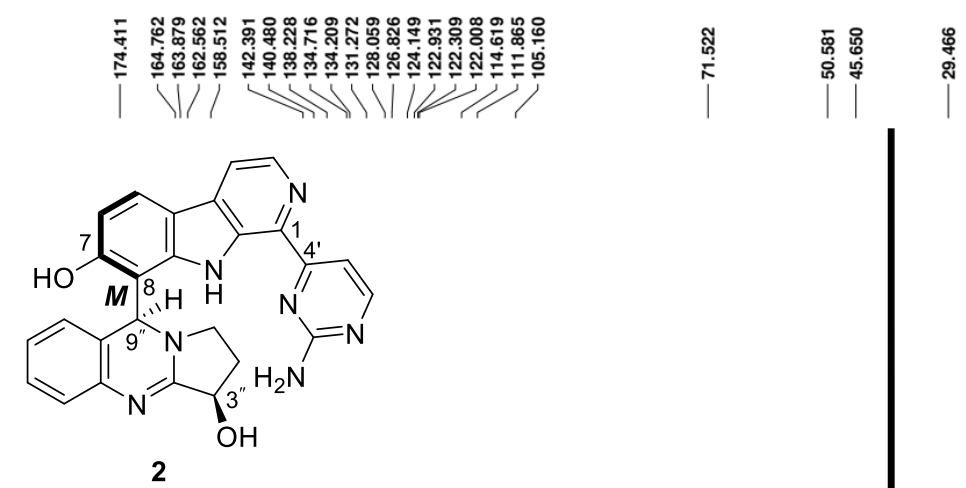


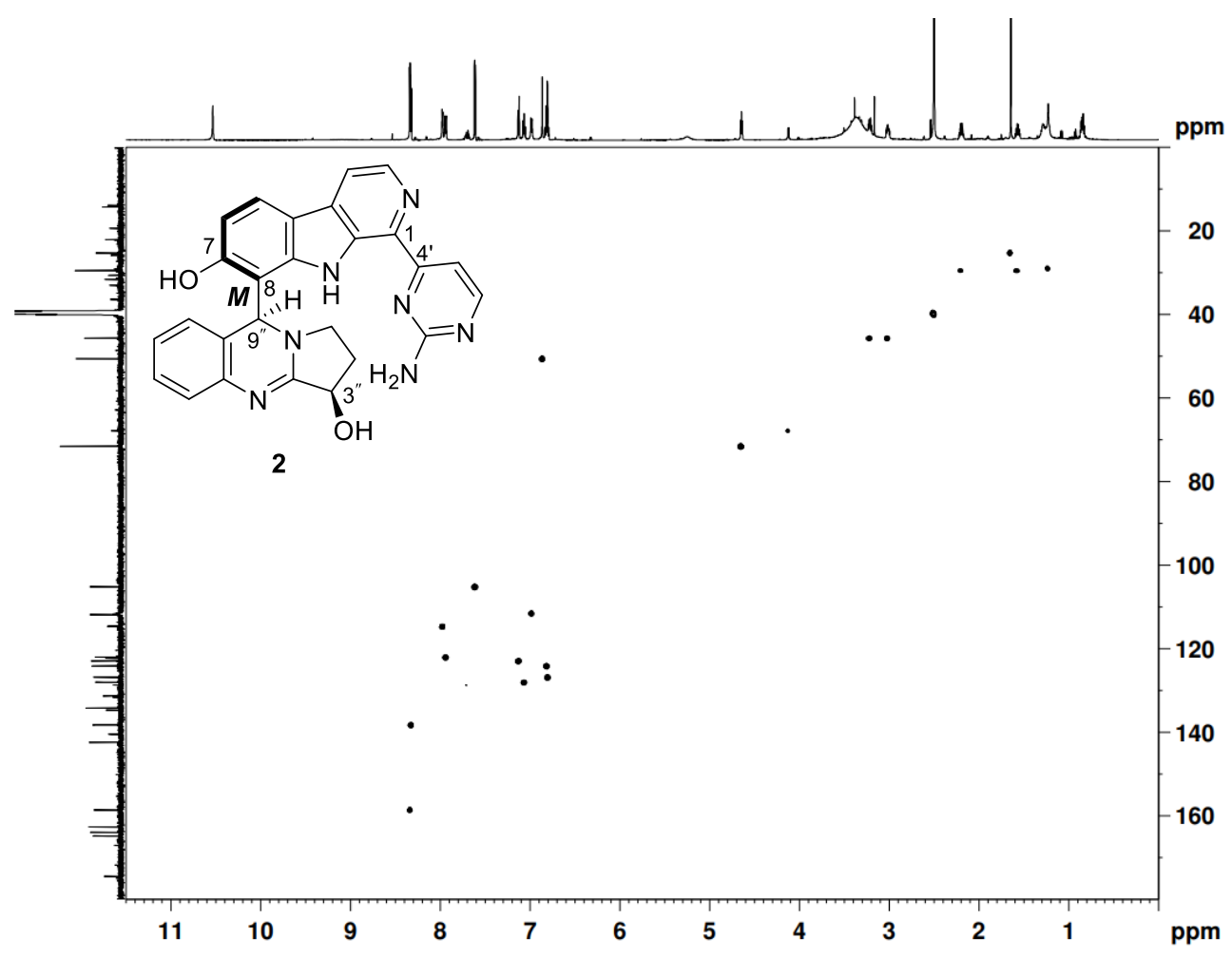

Figure S20 HSQC spectrum of $\mathbf{2}$ in DMSO- $d_{6}$

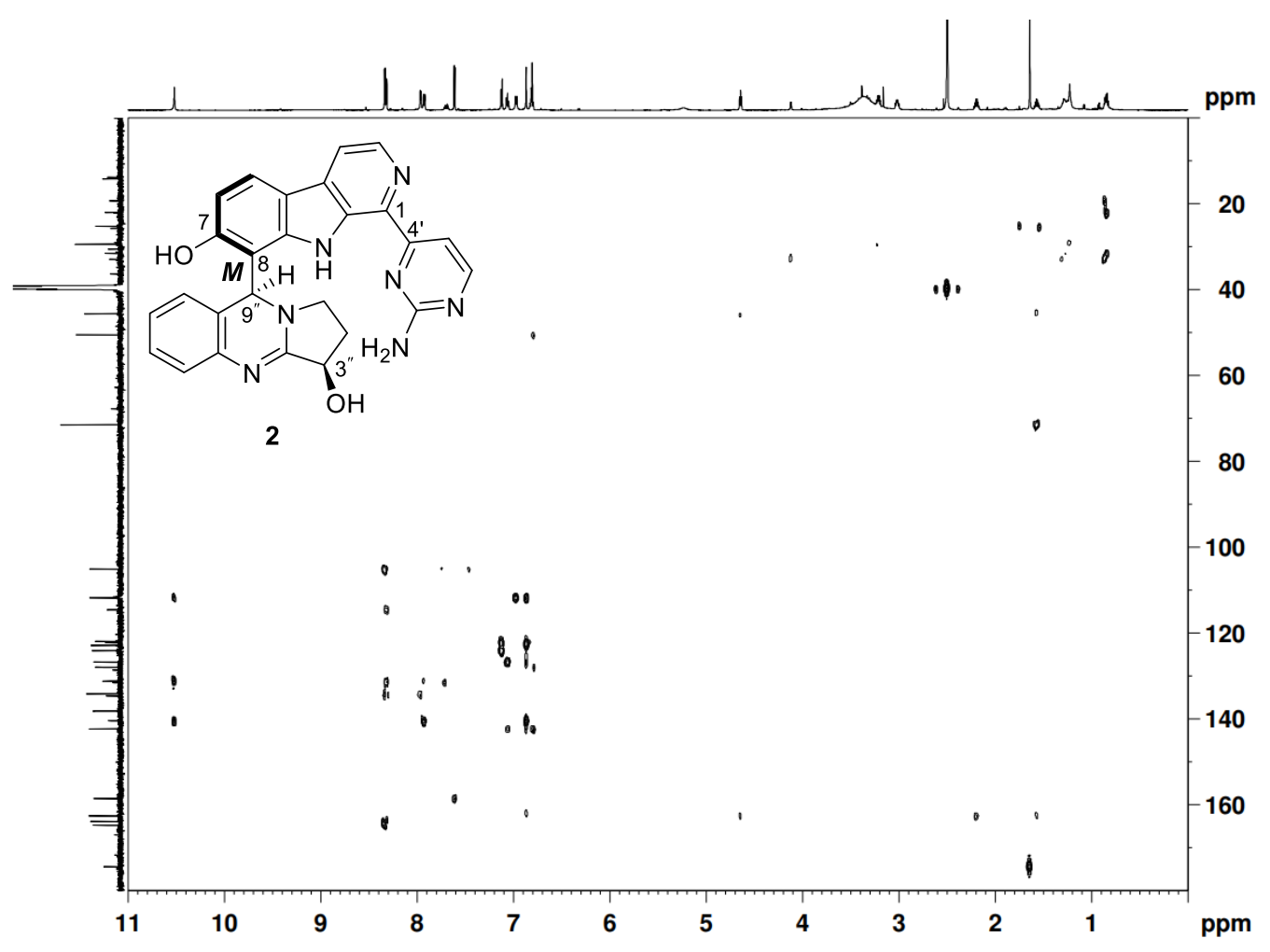

Figure S21 HMBC spectrum of 2 in DMSO- $d_{6}$ 


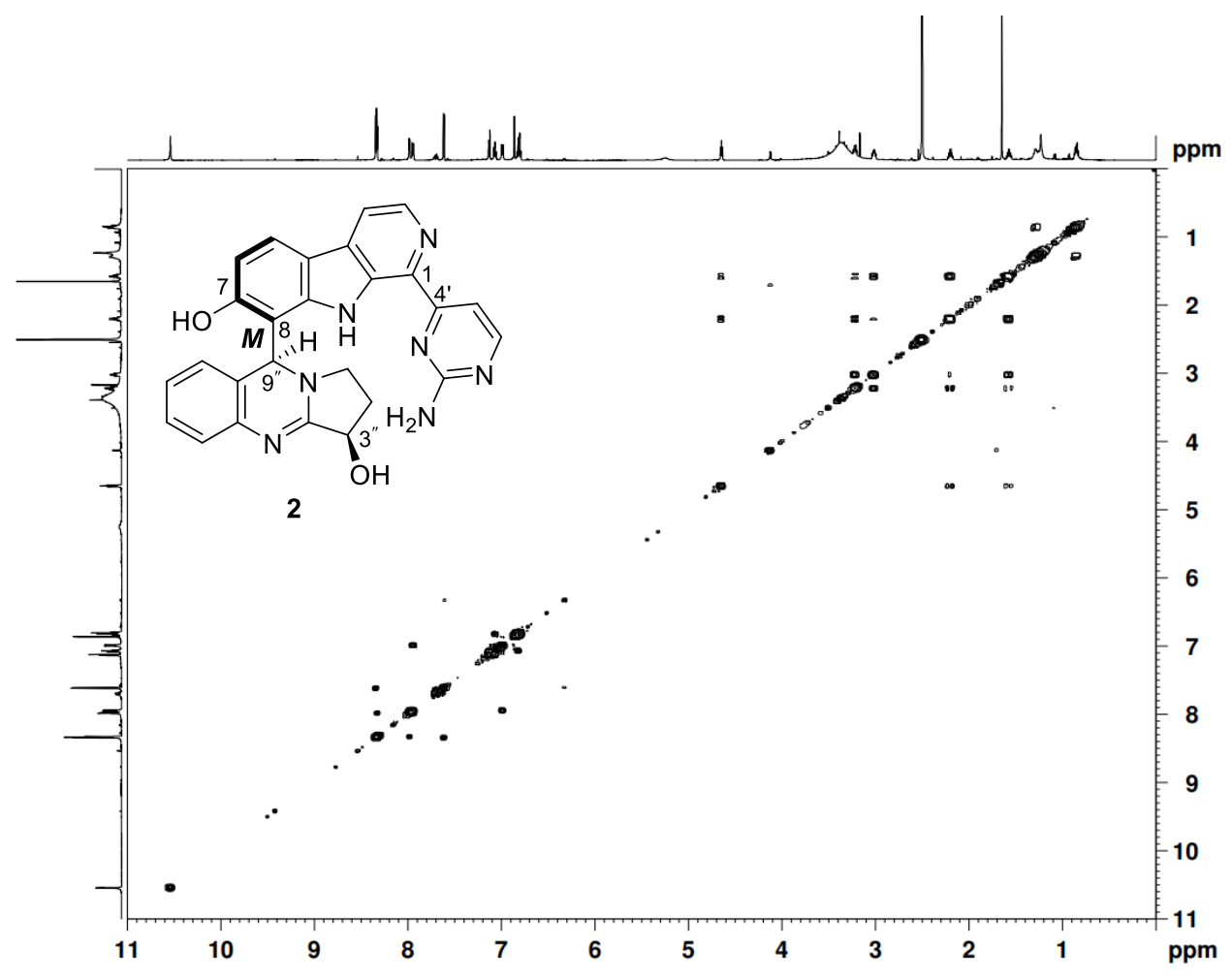

Figure $\mathbf{S 2 2}{ }^{1} \mathrm{H}-{ }^{1} \mathrm{H}$ COSY spectrum of $\mathbf{2}$ in DMSO- $d_{6}$

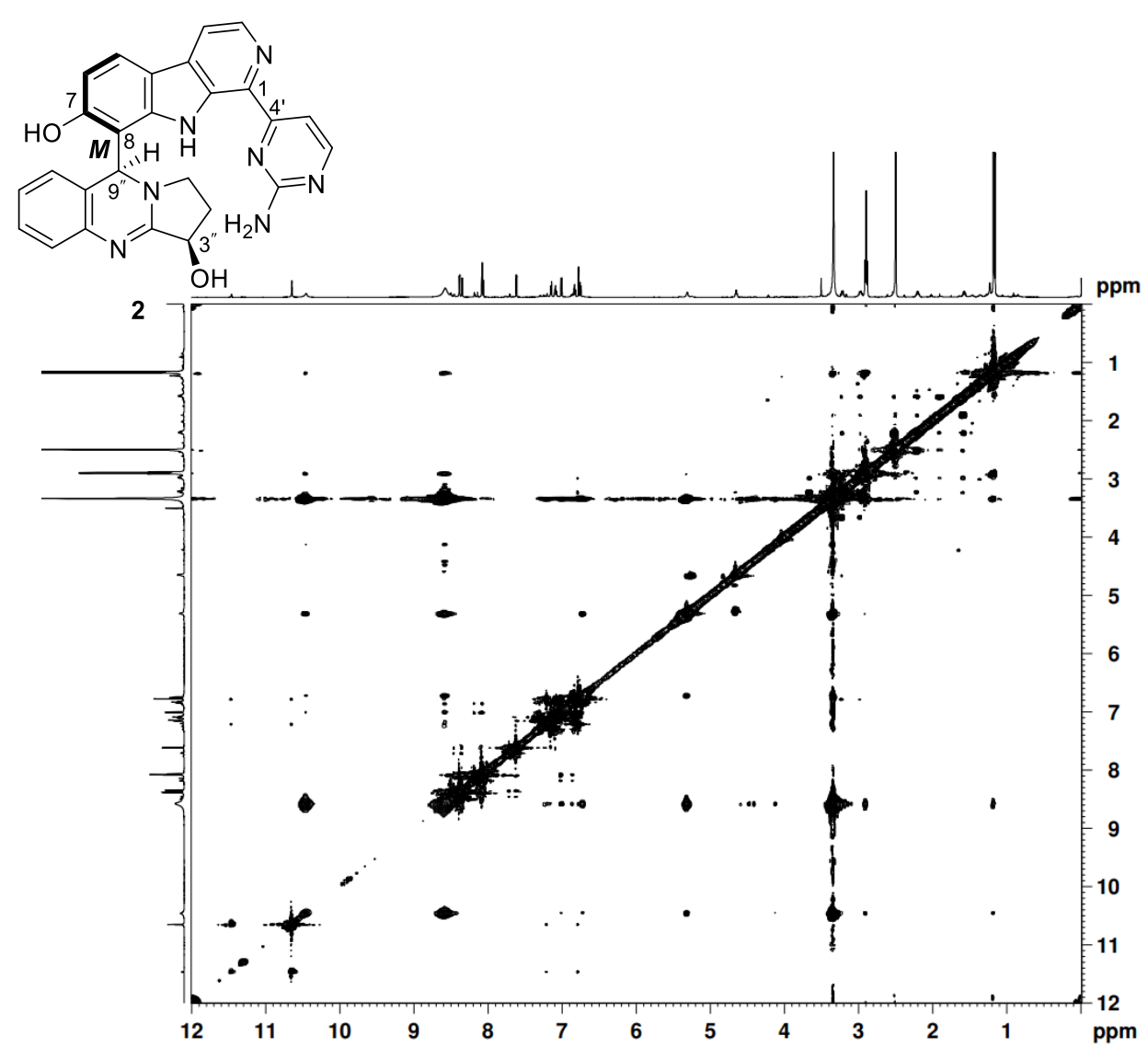

Figure S23 NOESY spectrum of $\mathbf{2}$ in DMSO- $d_{6}$ 


\section{Mass Spectrum SmartFormula Report}

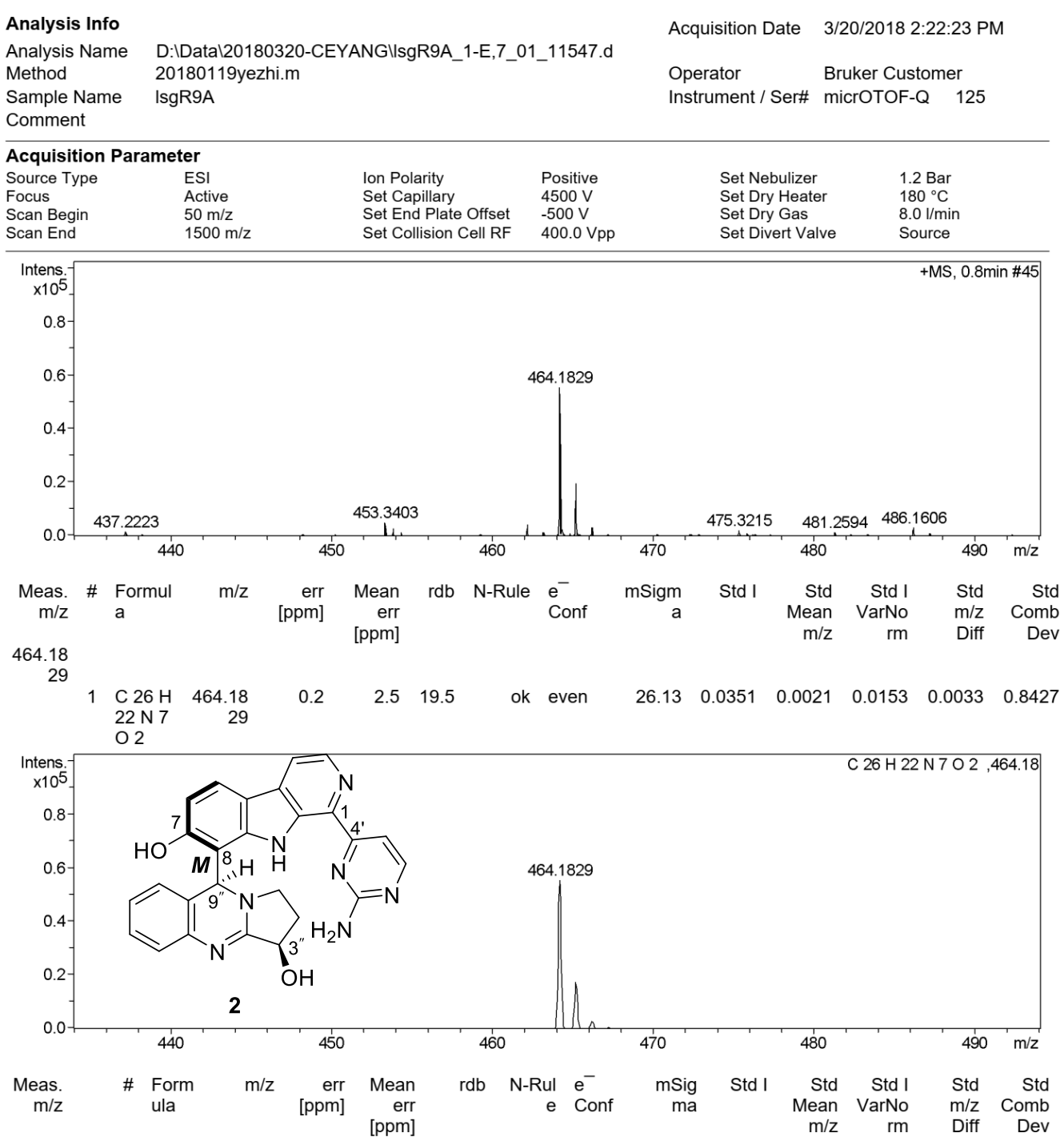

\begin{tabular}{llll}
\hline Bruker Compass DataAnalysis 4.0 & printed: & $3 / 20 / 2018$ 3:27:18 PM & Page 1 of 1
\end{tabular}

Figure S24 HRESIMS spectrum of $\mathbf{2}$ 
Data Set: 没有
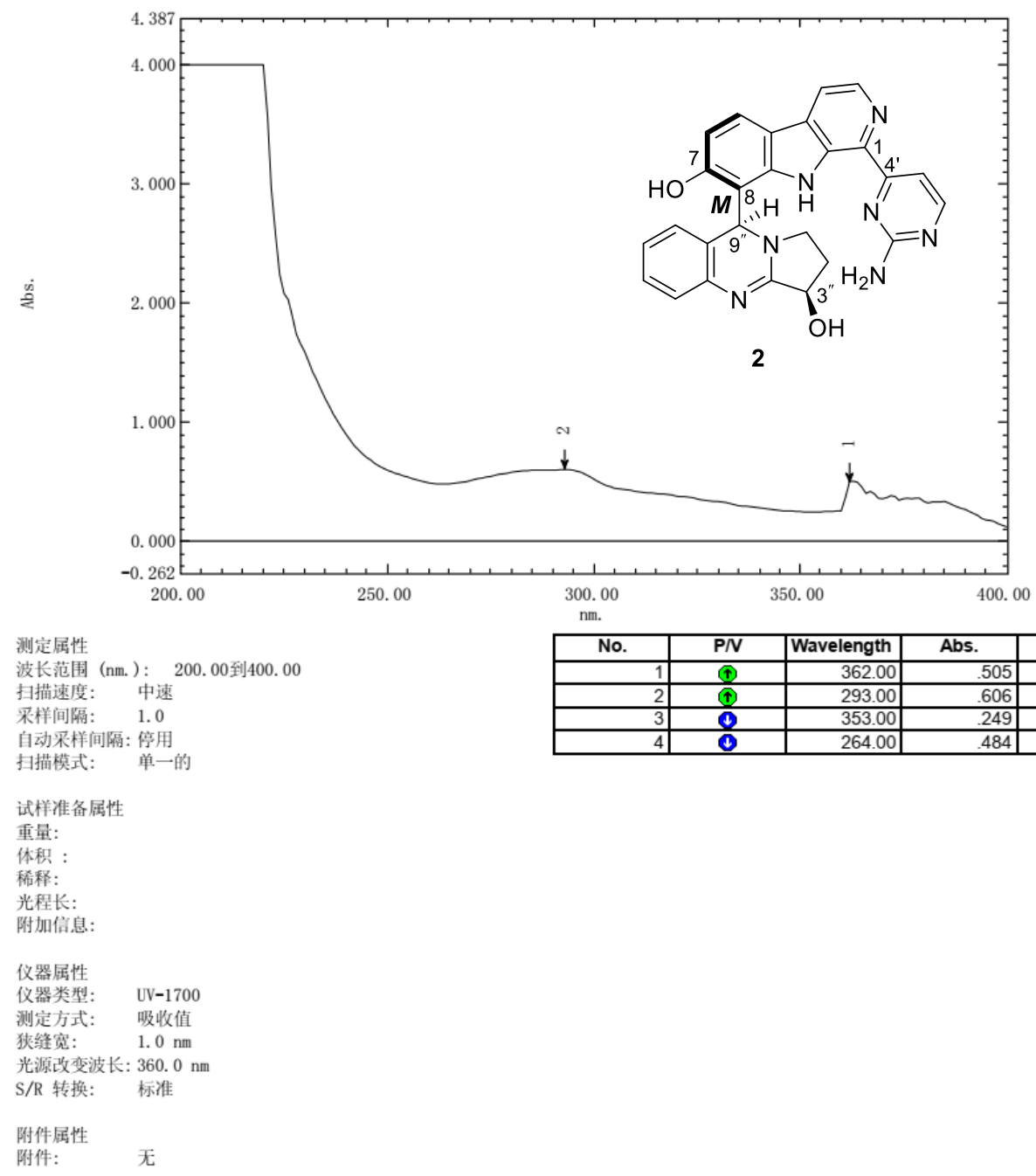

Figure S25 UV spectrum of 2 in $\mathrm{MeOH}$ 


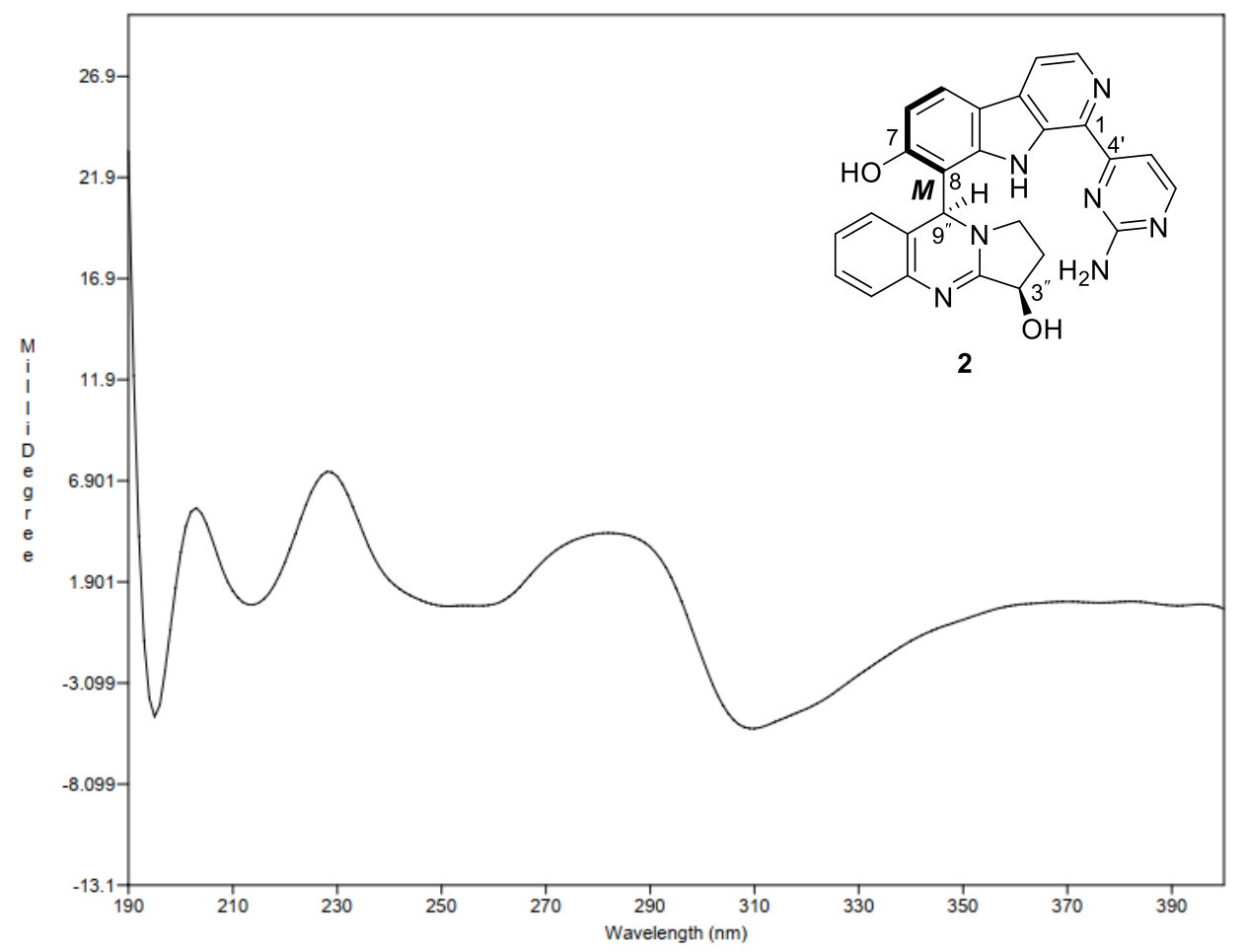

Bio-Kine Software V4.74 Date : 2020-1-2 Time : 11:46:32

COMMENTS :

File name : sav-golay

Savitzky-Golay Smooth of sav-golay

Window Points $=15$

Polynomial Order $=3$

Derivative $=0$

Figure S26 Experimental ECD spectrum of 2 in $\mathrm{MeOH}$

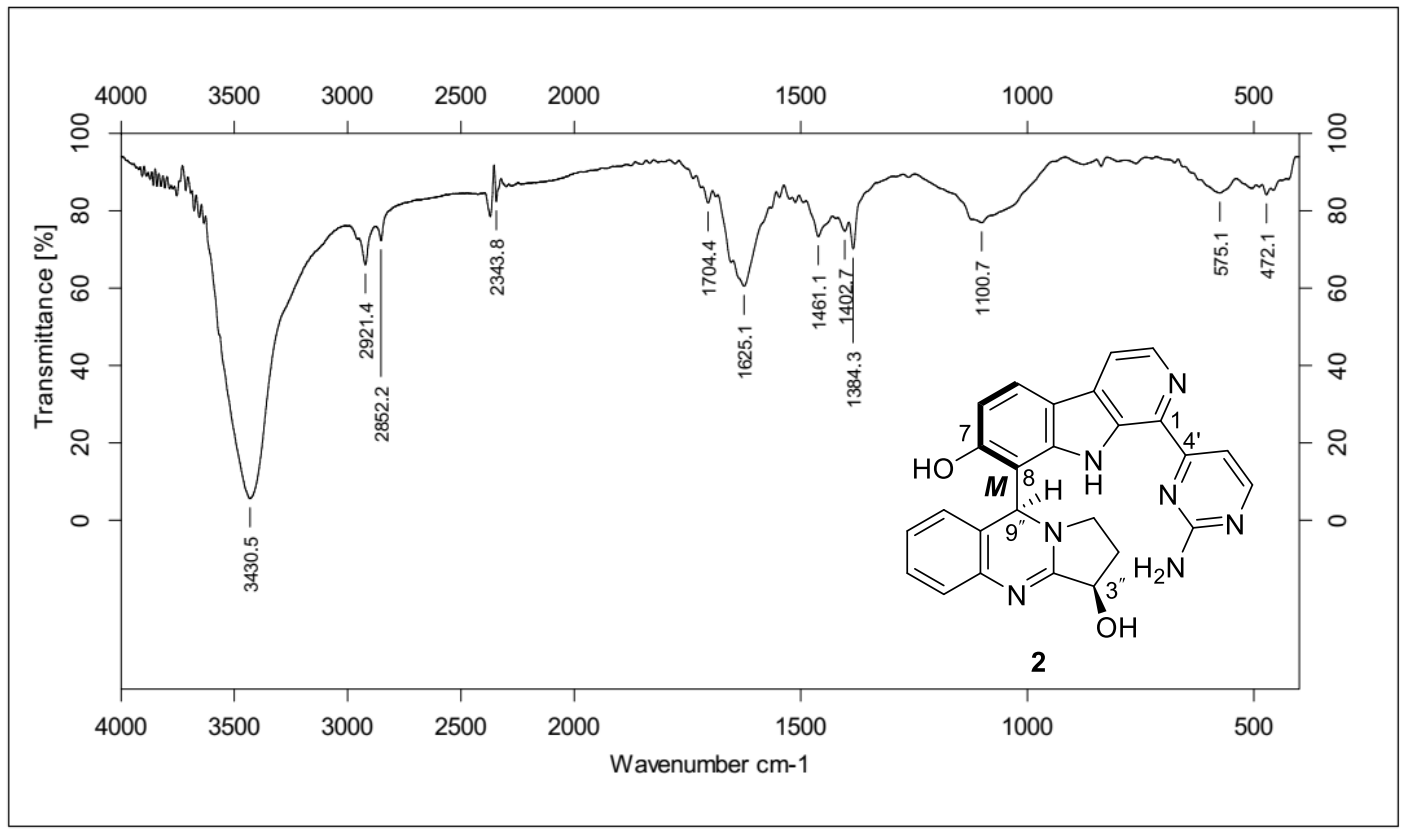

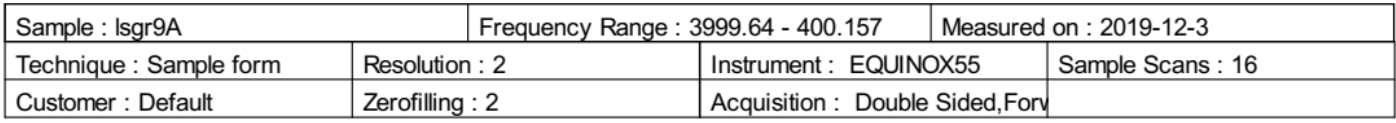

Figure S27 IR spectrum of 2 